\title{
Delving into the Divisive Waters of River Basin Planning in Bolivia: A Case Study in the Cochabamba Valley
}

\author{
Nilo Lima-Quispe ${ }^{1}$, Cláudia Coleoni ${ }^{1}{ }^{1}$, Wilford Rincón ${ }^{2}$, Zulema Gutierrez ${ }^{3}$, Freddy Zubieta ${ }^{3}$, Sergio Nuñez ${ }^{3}$, \\ Jorge Iriarte ${ }^{4}$, Cecilia Saldías ${ }^{3}$, David Purkey ${ }^{1}$, Marisa Escobar ${ }^{5}$ and Héctor Angarita ${ }^{1, *}$ \\ 1 Latin America Center, Stockholm Environment Institute, Calle 71 No. 11-10, 110231 Bogotá, Colombia; \\ nilo.lima@sei.org (N.L.-Q.); claudia.coleoni@sei.org (C.C.); david.purkey@sei.org (D.P.) \\ 2 Independent Consultant, 170001 Manizales, Colombia; wrinconarango@gmail.com \\ 3 Independent Consultant, 2500 Cochabamba, Bolivia; zlgutierrez@hotmail.com (Z.G.); \\ z_freddy@hotmail.com (F.Z.); sertau93@gmail.com (S.N.); cecisaldias@gmail.com (C.S.) \\ 4 Independent Consultant, 703030 Sucre, Bolivia; iriartejorge@gmail.com \\ 5 Stockholm Environment Institute, Davis, CA 95616, USA; marisa.escobar@sei.org \\ * Correspondence: hector.angarita@sei.org
}

check for updates

Citation: Lima-Quispe, N.; Coleoni, C.; Rincón, W.; Gutierrez, Z.; Zubieta, F.; Nuñez, S.; Iriarte, J.; Saldías, C.; Purkey, D.; Escobar, M.; et al. Delving into the Divisive Waters of River Basin Planning in Bolivia: A Case Study in the Cochabamba Valley. Water 2021, 13, 190. https:// doi.org/10.3390/w13020190

Received: 31 October 2020 Accepted: 5 January 2021

Published: 14 January 2021

Publisher's Note: MDPI stays neutral with regard to jurisdictional clai$\mathrm{ms}$ in published maps and institutional affiliations.

Copyright: $(\odot 2021$ by the authors. Licensee MDPI, Basel, Switzerland. This article is an open access article distributed under the terms and conditions of the Creative Commons Attribution (CC BY) license (https:// creativecommons.org/licenses/by/ $4.0 /)$.

\begin{abstract}
River basin planning in Bolivia is a relatively new endeavor that is primed for innovation and learning. One important learning opportunity relates to connecting watershed planning to processes within other planning units (e.g., municipalities) that have water management implications. A second opportunity relates to integrating watershed management, with a focus on land-based interventions, and water resources management, with a focus on the use and control of surface and groundwater resources. Bolivia's River Basin Policy and its primary planning instrument, the River Basin Master Plan (PDC in Spanish), provide the relevant innovation and learning context. Official guidance related to PDC development lacks explicit instructions related to the use of analytical tools, the definition of spatially and temporally dis-aggregated indicators to evaluate specific watershed and water management interventions, and a description of the exact way stakeholders engage in the evaluation process. This paper describes an effort to adapt the tenets of a novel planning support practice, Robust Decision Support (RDS), to the official guidelines of PDC development. The work enabled stakeholders to discern positive and negative interactions among water management interventions related to overall system performance, hydrologic risk management, and ecosystem functions; use indicators across varying spatial and temporal reference frames; and identify management strategies to improve outcomes and mitigate cross-regional or inter-sectorial conflicts.
\end{abstract}

Keywords: water resources systems; participatory modeling; river basin planning; watershed management; water scarcity; water conflicts; Robust Decision Support; WEAP; Integrated Water Resources Management; Bolivia

\section{Introduction}

Water resources managers worldwide face high levels of natural and human-induced hydrologic variability accompanied by climate change projections [1] suggesting increased risks of water scarcity [2]. Defining future changes in hydrologic variability is highly uncertain, hindering the prediction of extreme events such as floods and droughts [3]. In addition to hydrologic variability, water managers deal with growing long-term demands for water from rapidly expanding urban areas and increased consumption across sectors such as agriculture and energy [4]. The intensification of human-water interactions reaffirms the need for 'good governance' to improve water management [5,6]. As the UN World Water Development Report [7] stated, "the world's water crisis is one of water governance, essentially caused by the ways we mismanage water". Under scenarios of deep uncertainty, water governance approaches should support water-related decision making [1]. The recognition of the interconnected nature of the biophysical and socioeconomic factors 
that converge in water management has resulted in the progressive adoption of integrative governance approaches, such as the Integrated Water Resources Management (IWRM) [8,9]. The IWRM framework has been widely adopted as a template for water governance $[10,11]$ and was recently included as an implementation target for the Sustainable Development Goal (SDG) 6 'Water and Sanitation' [12]. Numerous countries, including Bolivia, have attempted to adapt IWRM to their contexts and realities in the hope of improving outcomes in river basins characterized by scarcity and conflict. At its core, IWRM relies on placing biophysical and technical knowledge that is comprehensively developed at the scale of a river basin planning unit at the center of stakeholder interactions designed to identify integrated and coherent river basin scale solutions [8,9]. However, efforts to evaluate the river basin scale performance of specific interventions does not necessarily align with an individual stakeholder's more parochial objectives and interests. Nonetheless, within existing water policy frameworks, such as the European Water Framework Directive and many others, the river basin is commonly defined as the predominant spatial domain for water management, superseding other territorial and administrative boundaries [13,14]. The river basin unit also drives water management governance, generating new regulatory frameworks and institutional arrangements such as river basin organizations to promote the participation of multiple water users and civil society [15-17]. However, the river basin perspective may lead to potential conflicts or ambiguities with other existing levels of territorial governance more connected to individual stakeholder interests or frames of reference, such as municipalities or targeted water management entities (e.g., water utilities, irrigation districts). Although river basins certainly do define useful 'natural' boundaries [18,19], river basin management is also a result of 'political' processes and choices based on values and preferences often defined at sub-watershed scales, based on administrative boundaries $[20,21]$.

Although the IWRM framework is often used interchangeably with the concept of water governance, Lautze et al. [22] warn that "setting pre-determined goals or outcomes associated with IWRM circumscribes a major role of water governance-that of determining goals". In practice, the attempt to uniformly apply IWRM principles leads to 'poor' rather than 'good' water governance since local conditions, preferences, and values would remain largely misrepresented [22]. Ensuring engaged and effective participation from across sub-basin jurisdictions is key to address collective action dilemmas arising from diverse and potentially conflicting users' interests over Common Pool Resources such as a shared river basin [23]. Human-water interactions are often characterized by mismanagement (e.g., depleted, overused water) and ecosystem impairment [24], threating the water commons. For instance, in river basins, collective action dilemmas can lead to unsustainable water use and insufficient or unsafe water supply for downstream users [25]. This is surely contrary to the interests of some sub-basin stakeholder interests. A common approach toward representing sub-basin interests within a comprehensive river basin scale planning process involves developing analytical tools sufficiently disaggregated to capture the diversity of conditions and interest within the river basin planning unit. Many approaches and case studies pertaining to the use of models to simulate water resources system are available in the literature, which are addressed and discussed by Mashaly and Fernald [26].

Mirchi et al. [27] define three modeling approaches in support of water resources planning and decision making: predictive simulation, integrated descriptive models, and participatory models. The first case predicts the future behavior of a particular subsystem, such as hydrological conditions [27], based on output from a calibrated and validated historical model [26]. The second case adopts a more holistic approach allowing for feedback between two or more disparate subsystems such as hydrological, social, ecological, economic, and political based on historical patterns of interaction [27]. The third approach promotes the participation of decision makers and stakeholders in the modeling process $[26,27]$ where they can express their interests [28]. This approach allows for the performance evaluation of interventions in the face of changing climate or evolving so- 
cietal prerogatives [29-32]. This requires an understanding of the relationships between climate, water resources, and user expectations, which can be addressed using integrated hydrological/water management modeling tools [33] that quantify potential impacts at varying spatial and temporal scales [34]. For instance, the Water Evaluation and Planning system (WEAP) [35] has been applied in several river basins worldwide as a simulation model for decision support while considering multiple objectives [36-38]. The Sacramento Water Allocation Model, known as SacWAM, is an example of a WEAP-based hydrologic and system model that illustrates the complex water system operation, besides showing how its water would flow if there were no dams, diversions, or infrastructure [39]. The use of modeling tools allows water resources managers and stakeholders to identify the operational, institutional, or infrastructure interventions that meet the disparate goals set out for a water system [4]. Although participatory frameworks for decision making under uncertainty have been increasingly applied to water resources management [40,41], major challenges remain, such as dealing with trade-offs between multiple goals and addressing various sources of uncertainty in contested political processes [4]. There are many barriers to the implementation of participatory decision support approaches-limited capacities in local institutions, associated costs, implementation time, the challenge of designing an adequate methodological framework, and the sustainability of the process in the long term [28]. In addition to these barriers, the knowledge and methods to tackle uncertainties should be considered in learning and decision-making processes [42].

If the goal is to avoid collective action dilemmas, the analytical tools used to evaluate potential water management interventions must, beyond basin-level consideration, align with river basin sub-jurisdictions and sectorial interest [15]. The complexity of this challenge is multi-fold:

- there must be a clear connection between the model scope and disaggregated user concerns, interests, and goals [26];

- there must be an appropriate level of granularity, i.e., fixed-scale models are often either too large to allow analysis of small-scale issues that affect communities and ecosystems, or too small to address connections with the river basin-scale drivers or imperatives [43];

- there must be a common language and a channel of communication between the model and the diverse stakeholders [44];

- the model must be credible, i.e., modeling as a representation of reality can be very subjective unless guided by stakeholders' perceptions [45].

The Robust Decision Support (RDS) framework proposed by Purkey et al. [46] consists of an iterative bottom-up process with active stakeholder participation where decisions are supported by the use of water resources models, which are accompanied by a strong process of local capacity building. Case studies for RDS include urban water management in the metropolitan region of La Paz/El Alto, Bolivia [47], evaluation of climate change impacts in a large basin in northern Patagonia, Argentina [36], and implementation of an IWRM planning process in the Yuba River basin, California [46,47]. This paper presents innovations in the RDS participatory framework as a contribution to Bolivia's National Watershed Policy, specifically in the formulation of the Rocha River Basin Master Plan (PDC in Spanish), which is located in the Cochabamba Valley, Bolivia. This effort took place within Bolivia's unique historical and political context related to water management. Our methodological approach consists of combining the RDS framework for water resources management [46] to extend Bolivia's guiding framework for the formulation of river basin master plans. We address the following questions: How does the water resources system model respond to water-related decision-making processes and institutional governance design at a range of scales within a river basin? How does the water resources system model contribute to the development of effective water planning instruments? 


\section{Materials and Methods}

\subsection{Study Area}

The Rocha River Basin is located in the department of Cochabamba in the Plurinational State of Bolivia and contains all or part of 25 rural and urban municipalities (Figure 1). The basin has an area of approximately $3699 \mathrm{~km}^{2}$ and a population of almost 1,300,000 people (13\% of the country). From the hydrological point of view, it is comprised of three sub-basins: Rocha, Maylanco, and Sulty (also known as Valle Alto). The Rocha and Maylanco sub-basins-for decades predominantly agricultural areas-are rapidly urbanizing, including cities such as Cochabamba, Sacaba, Colcapirhua, Vinto, Tiquipaya, and Sipe Sipe, which make up the greater Cochabamba metropolitan area. In contrast, the Sulty sub-basin is mainly rural, with agriculture as its primary economic activity. Climatically, $80 \%$ of the annual precipitation is concentrated between the months of December and March (rainy season), $2 \%$ between the months of May and August (dry season), and the remaining precipitation in the months of the transition seasons (April, September to November) [48]. Annual rainfall varies between 300 and $900 \mathrm{~mm}$, wetter to the north and the east, where most of the water supply reservoirs and current and potential sources of inter-basin transfer are located (Figure 1).

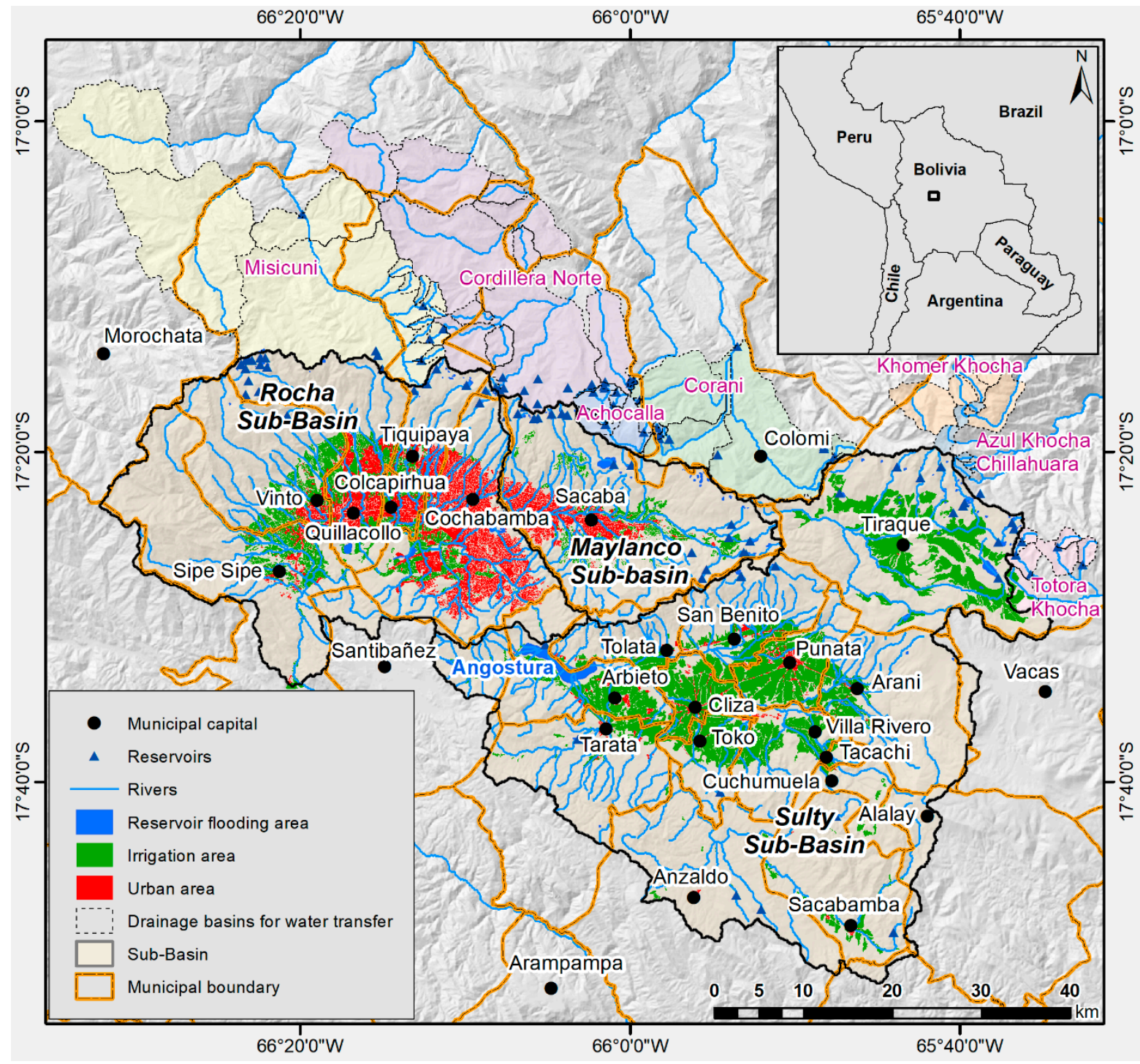

Figure 1. The Rocha River Basin and its geographical environment related to the urban area, agriculture, and the different hydrographic elements. 
Challenging climatic conditions are likely to worsen under projected climate conditions. Previous studies have developed climate change scenarios on a basin scale for the 2020-2050 horizon, based on Intergovernmental Panel on Climate Change (IPCC)5th Phase of the Coupled Model Intercomparison Project (CMIP5) climate models prioritized based on their capacity to capture long-term historical (observed) climate variability attributes in the period 1981-2005 [48]. According to the Institut Pierre-Simon Laplace Climate Model 5A Low-Resolution (IPSL-CM5A-LR) [49] model for Representative Concentration Pathway 8.5 (RCP8.5) [50], the annual precipitation could be reduced by $7 \%$. In some months of the rainy season (February and March), precipitation could be reduced by up to $30 \%$. In the remaining months of the rainy season (December and January), it could increase by up to $11 \%$. The dry season could be even drier with reductions of up to $77 \%$. In the transition season, particularly between September and November, reductions in precipitation of between 10 and $20 \%$ are also expected. The average temperature could increase by $1.1^{\circ} \mathrm{C}$.

Given these challenging climatic conditions, it is not surprising that the Rocha River has historically been affected by water supply problems. Limited water availability due to the prevailing semi-arid climate as well as long-standing conflicts over access, governance, and environmental degradation contribute to the basin's water-related challenges. Cochabamba, Bolivia's third largest city, has experienced conflicts over the expansion of water access, particularly in the rural areas, highlighting the complexity of rural-urban hydrosocial relations [51] where established water users confront emerging water use communities. The Cochabamba Water War (la Guerra del Agua) emerged as a conflict between a centralized, foreign and private water company and urban residents over water tariffs that increased by as much as $200 \%$ [52,53], internationally recognized as a "David versus Goliath success" [53,54]. Empowered by the success of the Water War, the peri-urban water committees (comités de agua) moved toward more decentralized, small-scale, and autonomous water management led by community-owned supply systems [52]. However, this shift led to large disparities in water access in many extensive areas of the basin where small-scale options based on the water availability in the immediate environment were no longer compatible with the current levels of water demands. In response, new centralized water transfer projects from neighboring basins [51] with favorable quantity and quality conditions emerged as options [55]. The construction and expansion of some water transfers is currently underway; yet, local water managers also seek short-term solutions [52] such as drilling wells to extract water from aquifers. In addition to these problems, the region is exposed to hazards such as floods [56], landslides, debris flow, and droughts. The quality of surface water [57] and groundwater is degraded by the direct discharge of domestic and industrial wastewater, which is later re-used in irrigation [58-60]. In addition, the absence of effective land planning policies has been causing unregulated urban growth to the detriment of agricultural areas, aquifer recharge zones, and national parks [61]. This is hardly the setting for successful river basin-scale decision making, more so in the absence of sufficient comprehensive basin-scale information.

\subsection{Bolivia's Basin Plan in the Context of the River Rocha Basin Planning}

Nonetheless, similar to other countries, Bolivia has progressively adopted the river basin as the spatial domain for water management. However, it is worth noting that Bolivia's original Integrated River Basin Management (IRBM) approach adopted more of a terrestrial focus rather than a focus on water resources. Small-scale actions such as soil conservation, forest conservation, afforestation and reforestation, flood control, and bank protection civil works were the focus. For instance, the 1991 Cochabamba's Integrated River Basin Program (Programa de Manejo Integral de Cuenca, PROMIC) [62] was a national IRBM reference in the implementation of projects aimed at reducing local damage from flood events in prioritized river basins. This created an expectation that large-scale river basin plans would justify small-scale, community-level interventions. 
This expectation aligned with customary practices in the Andean region of Bolivia known as customs and habits (usos y costumbres) that establish a relationship between water management and existing local governance in communal territories [63,64]. In this context, "water belongs to the territory and the territory belongs to the community" $[63,65]$. However, by the 2000s, Bolivia expanded the initial terrestrial-oriented scope to incorporate the social, environmental, and sectoral dimensions in water resources management [66]. The combination of the IWRM and IRBM approaches attempt to represent both the socioeconomic dimension and the natural resources conditions of the river basin, broadening the national concept of water governance beyond strictly local imperatives. However, the IWRM and IRBM approaches may not offer an appropriate representation of water management for complex community-managed water supply systems [67] upon which large-scale water resources management intervention are superimposed.

Bolivia's Ministry of the Environment and Water (MMAyA for its Spanish initials) has developed the conceptual framework and the national policy for IWRM and IRBM through the National Basin Plan (PNC in Spanish), which was promulgated in 2006. The PNC framework seeks to deliver solutions to integrated land and water-related problems with intervention justified within a PDC. The PDC is a planning instrument aimed at establishing intergovernmental and intersectoral coordination to develop water resource governance [68]. An early effort at PDC development occurred within the Rocha River Basin before systematic learning from other implementation experiences became available [69]. The Cochabamba Departmental Government originally formulated strongly IRBM-oriented and less so IWRM-oriented guidelines for the Rocha River Basin in 2014 [70], hampering the implementation of the proposed plan, as there was little buy-in among the 25 basin municipalities to implement large-scale water management interventions. In the Cochabamba Valley, competing sectoral and regional (i.e., upstream vs. downstream) interests such as household water users, rural communities, and civic organizations in urban areas make intersectoral coordination extremely difficult to achieve. As a result, the MMAyA and the Cochabamba Departmental Government decided to update the planning instrument by formulating a package of medium- and long-term actions based on three main factors:

- climate change considerations;

- the development of analytical tools;

- the broad participation of key stakeholders in the basin.

\subsection{Proposed Approach}

The RDS framework developed by Purkey et al. [23] and Bolivia's guiding framework of the PDCs [11] provided our methodological approach for the formulation of a river basin master plan supported by participatory water resources systems modeling (Figure 2). The RDS framework has two phases: (i) preparation and formulation and (ii) evaluation and agreement. The first phase has six steps to identify the current and future vulnerability of the system. The second phase is a three-step participatory-driven process for the assessment of different management options leading to the identification of robust actions (actions that can satisfy disparate objectives under the assumed uncertainties). An essential step of this framework is the formulation of the problem using the XLRM matrix [71], where $(X)$ stands for the uncertainties, (L) stands for the management options, (R) stands for the analytical tools that relate the $(\mathrm{X})$ and $(\mathrm{L})$, leading to performance measures, and $(\mathrm{M})$ is used to evaluate the potential options. Uncertainties $(X)$ are generally not contentious, i.e., all interest groups can agree that climate change or demographic growth are uncertainties that have the potential to impact outcomes related to water management. In contrast, preferences related to sectoral or strategic actions (L) are contentious, as stakeholders can oppose strategies offered by others. Metrics of performance (M) are identified for each sector to evaluate the outcome of each strategy identified, the stakeholder's preferred strategy, as well as those offered by others. These metrics are independent of any strategy, enabling a sector-specific strategy to improve outcomes (M) defined by another sector. 
This is the basis of trade-off analysis and compromise, which serves for the formulation of a participatory-driven analysis in the decision process.
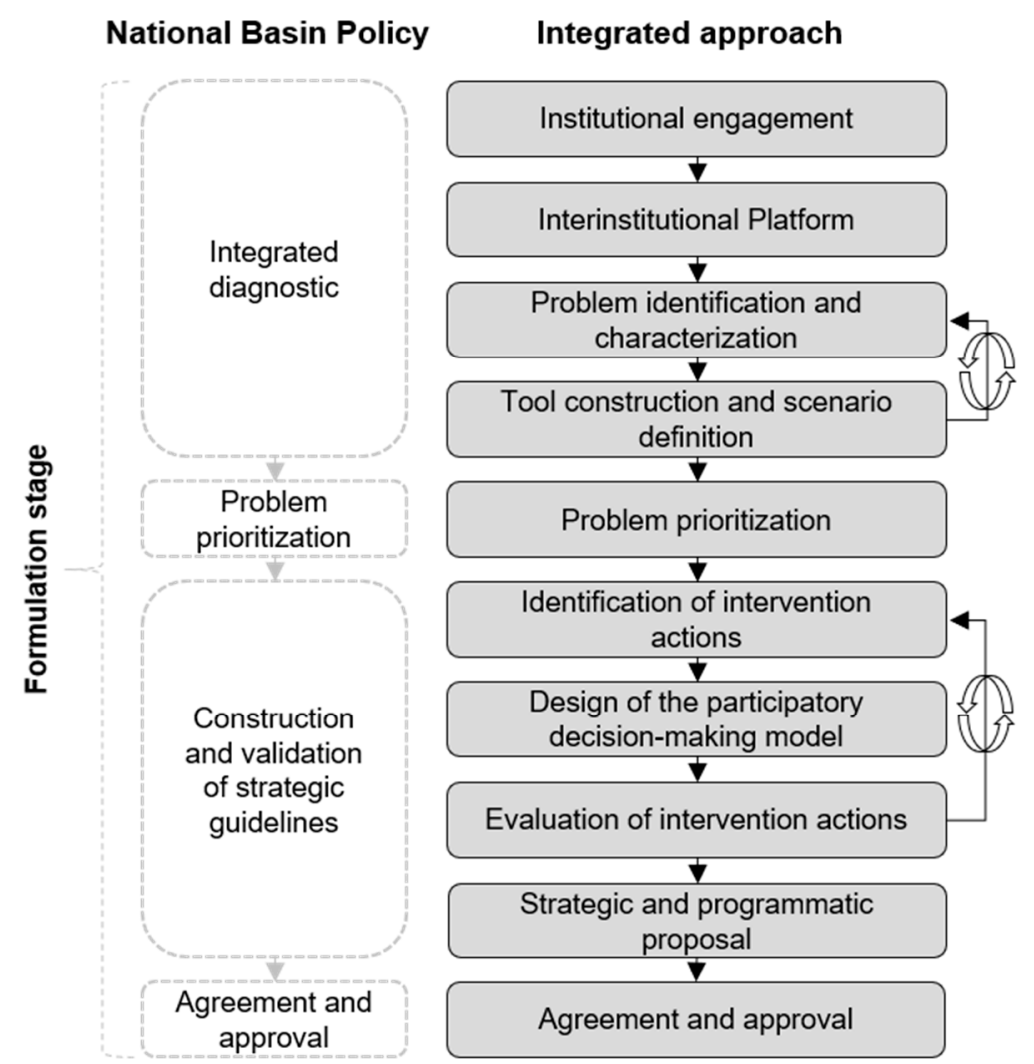

\section{Robust Decision Support}

Preparation and formulation:

- Define decision space

- Map key actors

- Problem formulation (XLRM)

- Tool construction

- Scenario definition

- System vulnerability

Evaluation and agreement:

- Options analysis

- Results exploration

- Decision making

Figure 2. Framework to develop a Basin Master Plan based on model-driven participatory-based decisions. The new approach (center panel) allows grounding and implementation of the National Basin Policy guidelines (left panel) [68] and the robust decision support approach (right panel) [46].

The guiding framework of the PDC contemplates three stages: formulation, implementation, and evaluation and monitoring. Each of these stages has a step-by-step process with general guidelines (Figure 2). All stages rely on public participation of the basin's institutions and actors as an essential element to promote environmental governance. The formulation stage comprises an integral participatory appraisal that allows for the identification and prioritization of the main objectives of basin and water management, albeit without the benefit of detailed modeling and analysis. This stage also considers the identification, construction, and validation of actions to achieve the proposed objectives. Stakeholder participation is a key element for the PDC guidelines and the RDS framework. The institutional approach and the mapping of key actors are considered at the beginning of the process for both cases.

The comparison of PNC guidelines with the RDS framework reveals several gaps within the PDC guidelines. These gaps reduce the capacity of the PDC guidelines to inform water management in Bolivia's river basins, including:

- The prioritization of problems is done only based on the historical time horizon without considering potential future changes generated by uncertain factors $(X)$ such as climate change, land-use change, population growth, etc.

- The application of water resources system models is limited to generating water balance data between supply and demand for historical conditions, and there is no use for modeling at this stage of evaluating trends or strategic actions. 
- The strategic actions lack quantitative performance indicators or measures (M) to help forecast progress toward medium- and long-term goals and objectives, to which models have a great potential to contribute effectively.

However, the RDS general template to approach decision processes requires adapting to the local particulars of water governance and institutional design. To use RDS effectively to support the development of a new Rocha River basin PDC, we oriented the framework toward the development of a participatory decision-making process. A novel component of the RDS process was the introduction of 'hard coupled' decision interfaces to the WEAP model to support participatory forums. This allowed diverse institutions, interests, and organizations-that benefit or are affected by the decisions of the basin's interventionto interactively explore the medium- and long-term implications of water management options, recognize disparities between their own and others' frames of reference, and share ideas to build a Master Plan. The implemented framework, shown in Figure 2, is detailed in the list below:

1. A mapping of key actors to identify the main institutional, sectoral, and civil society actors in basin and management problems.

2. The institutional engagement which, within the framework of the PDC, means the creation of the Inter-Institutional Platform as a space for the participation of the basin's stakeholders. This process is made up of the following instances: (i) the Board of Directors as the highest decision-making body, which is integrated by executive authorities from the national, departmental, and municipal levels; (ii) the Technical Council with representation from public institutions, non-governmental organization (NGOs), research institutes, and international cooperation initiatives; (iii) the Social Council as a space for dialogue and negotiation between the different social sectors such as water users, indigenous authorities, and civic organizations; and (iv) the Basin Management Unit (UGC) as the operational body for the implementation of the plan [11].

3. The identification of problems in the basin includes (i) participatory workshops, where problems must be addressed at appropriate levels of granularity, from the local to the regional scale and (ii) relevant indicators to assess those problems. This identification should be accompanied by the collection of existing information and fieldwork to characterize the problems and to construct a comprehensive database. Based on the participatory space and relevant information, a list of the uncertainties or uncertain factors $(X)$ that define the problems can be consolidated.

4. The development of models of water resources systems that fully respond to the problems identified and have the capacity and flexibility to incorporate different future uncertainties $(X)$ in the evaluation of intervention actions $(L)$. Given the participatory approach, this step requires the involvement of key stakeholders in providing additional information, feedback, and local expert opinion to validate models, and possible trajectories of uncertain factors.

5. The prioritization of problems through participatory workshops, where the problems initially identified are presented, but this time characterized with model output information for both historical and future conditions. Stakeholders can discuss and agree on the priorities and problems that require intervention in the short, medium, and long term based on quantitative and qualitative information; they can also define specific objectives for each prioritized problem.

6. The identification of intervention actions $(\mathrm{L})$ to achieve the specific objectives set. Since the PDC must connect to other planning instruments, it is important to start with the inventory of existing sectoral intervention actions and plans in the different territorial entities, mainly those in a pre-investment state. This will allow an analysis of how these actions contribute to the specific objectives and the need to identify additional actions for which participatory spaces can be generated. This should be accompanied by a characterization of the actions with basic technical information, the 
scope, reference costs, and social and environmental conflicts that may make their implementation unfeasible.

7. The design of the Participatory Decision-Making Model (PDM) (R) as a facilitationoriented tool for the construction of agreements between different actors, recognizing that there are coordination needs and that decision making is a process of negotiation between the different interconnected interests, which are not always coherent with each other. The PDM is made up of information, models of water resources systems, participation mechanisms, users, and use cases. The characteristics of the PDM are described in detail below:

a. It allows the consideration of action proposals from the different territorial levels. It provides an overview of the coherent actions' prioritization and implementation, recognizing the present biophysical, sectoral, and territorial interconnections that make the basin an indivisible planning unit.

b. The indicators $(\mathrm{M})$ that consider a system of hierarchical analysis units, which allows a nested measurement between working scales, and where the basin domain is represented by sub-units of different scales, starting from indicators in basic modeling units (i.e., micro-basin, irrigation zone, urban demand unit).

c. The specific objectives for the prioritized problems must be articulated with the general principles established in the national policy and planning instruments such as the PDC.

d. Their application is not limited only to the formulation stage but also to the other stages such as monitoring or follow-up. In the formulation stage, it allows a comparative and participatory analysis to be made over time, making it possible to differentiate between medium- and long-term horizons. In the monitoring and follow-up stage, it will have the capacity to review the fulfillment of goals and potential strategic adjustments and redirection.

e. The type and scope of intervention actions that become relevant in the performance of objectives and indicators at the intervention scales of a basin plan. Through the PDM, it is possible to evaluate the multiple effects (positive or negative) of the interaction of the various interventions.

f. With respect to both frameworks, the set of quantitative indicators that can operate at various scales and the use of an interactive decision panel connected to a water resources system model were important innovations. Co-designed with stakeholders, these innovations create a common language and interactive feedback of model runs to specific requirements.

8. The intervention actions identified in previous steps should be implemented in the PDM to evaluate performance using multiscale indicators. This can begin with a participatory and iterative exercise in evaluating individual actions in the medium and long term. Interactions between the actors and the PDM, and discussions of the different interests should lead to the formulation of intervention packages for different time horizons.

9. The action packages should be grouped into strategic lines and a coherent and plausible programmatic implementation framework with clearly established goals and potential funding options leading to the development of a formulation document to be approved by the stakeholders. Within the PDC framework, this refers to the Inter-Institutional Platform.

At the implementation stage, intervention actions can be reviewed and adjusted as new redirections are needed. The water resources system model can be updated with new information to help improve its performance. To make this effective, it is necessary to build local capacity in the management of all the tools that constitute the PDM.

\section{Implementation of the Proposed Approach}

The results of the implementation of the proposed approach in the formulation of the Rocha River PDC are presented below. 


\subsection{Strategic Modeling of the Basin's Water Resources}

The MMAyA and the Development Bank of Latin America (CAF) developed a previous instance of the Rocha River basin model using WEAP [48]. The modeling process included the following in the collection and systematization of available data: participatory co-development of the model, fieldwork, definition of scenarios, and discussions about the benefits of using models in support of river basin planning. The WEAP model of the basin includes hydrology, water demand and supply, rules of operation, use rights, and water quality in terms of organic contamination of the main rivers. The model has a monthly time step for a historical horizon of 1980-2015 and a prospective period of 2020-2050. Hydrology was implemented using WEAP's Soil Moisture Model (SMM) [35], which is a one-dimensional model based on the notion of water transfer between two buckets: an upper bucket representing the root zone and a lower bucket representing deep storage or regional aquifers (when applicable). These two buckets represent the dynamics between evapotranspiration, surface runoff, interflow, and percolation for each basic modeling unit (catchments). The model allows dividing the basin in catchments in a semi-distributed way. The SMM is forced with climate data such as precipitation, temperature, relative humidity, wind speed, and insolation. Climate data from the Bolivian Water Balance [72] were used as input. The SMM is also used to calculate irrigation demands in agricultural areas, which are obtained as deficits of water required to maintain soil moisture within desired boundaries following crop type and calendars and other technical restrictions such as distribution or application efficiency and water allocation priority.

The catchments were delimited based on the location of reservoirs, water use points, transfer basins, wastewater discharge, calibration points, and topographic transition zones between mountain and valley areas (Figure 3). To parameterize the hydrological model, vegetation coverage, slope, and geology were considered. The vegetation cover was classified with a Landsat 8 image (January 2018) for the following categories: agriculture, forest, dispersed vegetation, temporary flood areas, urban area, scrubland, badland, and water bodies. The slope was obtained from a HydroSHEDS digital elevation model (DEM) [73] for the following ranges: sloping $(<10 \%)$, strongly sloping $(10-15 \%)$, moderately steep $(15-30 \%)$, steep $(30-60 \%)$, and very steep $(>60 \%)$. Using the 1:100,000 scale geological map from Bolivia's Geological Mining Service, it was possible to differentiate the Quaternary deposits. We used this information to identify the zones of recharge and the three aquifers (Sacaba Valley, Cochabamba Valley, and Alto Valley) with high probability of groundwater occurrence.

For the modeling, the 48 existing reservoirs were considered (Figure 3), of which $90 \%$ have a storage capacity of less than $1 \mathrm{Mm}^{3}$ and are used for small-scale irrigation. In the rainy season, storage is prioritized, and in the transition and dry seasons, water volumes are released for irrigation according to the agricultural calendar. The reservoirs for human consumption are operated according to water demand. Information regarding physical characteristics and location was collected from the national inventory [74] and potential investment project database.

Household water demand was represented in WEAP as a function of population, per capita consumption, and average losses reported by the water distribution systems of each municipality. In the Rocha and Maylanco sub-basins, there are two types of service providers: Water and Sanitation Service Providers (EPSA) and Small-scale Local Operators (OLPE) [75]. The EPSA is an entity that depends on the municipal government and whose service area is limited to the urban area, and it is regulated by the corresponding authorities. The OLPE are autonomous community organizations or cooperatives that provide water service to their areas of immediate territorial occupation. For the modeling, a distinction has been made between the coverage of EPSA and OLPE. A total of 26 water demand nodes have been represented (Figure 3). Water quality in the main section of the Rocha River was represented in the model as the organic contamination constituents that determine biological oxygen demand (BOD) using the Streeter-Phelps model [76] and water temperature of the river. The modeled river section and assessment points are shown 
in Figure 3. The assessment points are located downstream of the wastewater treatment plant (WWTP) discharge.

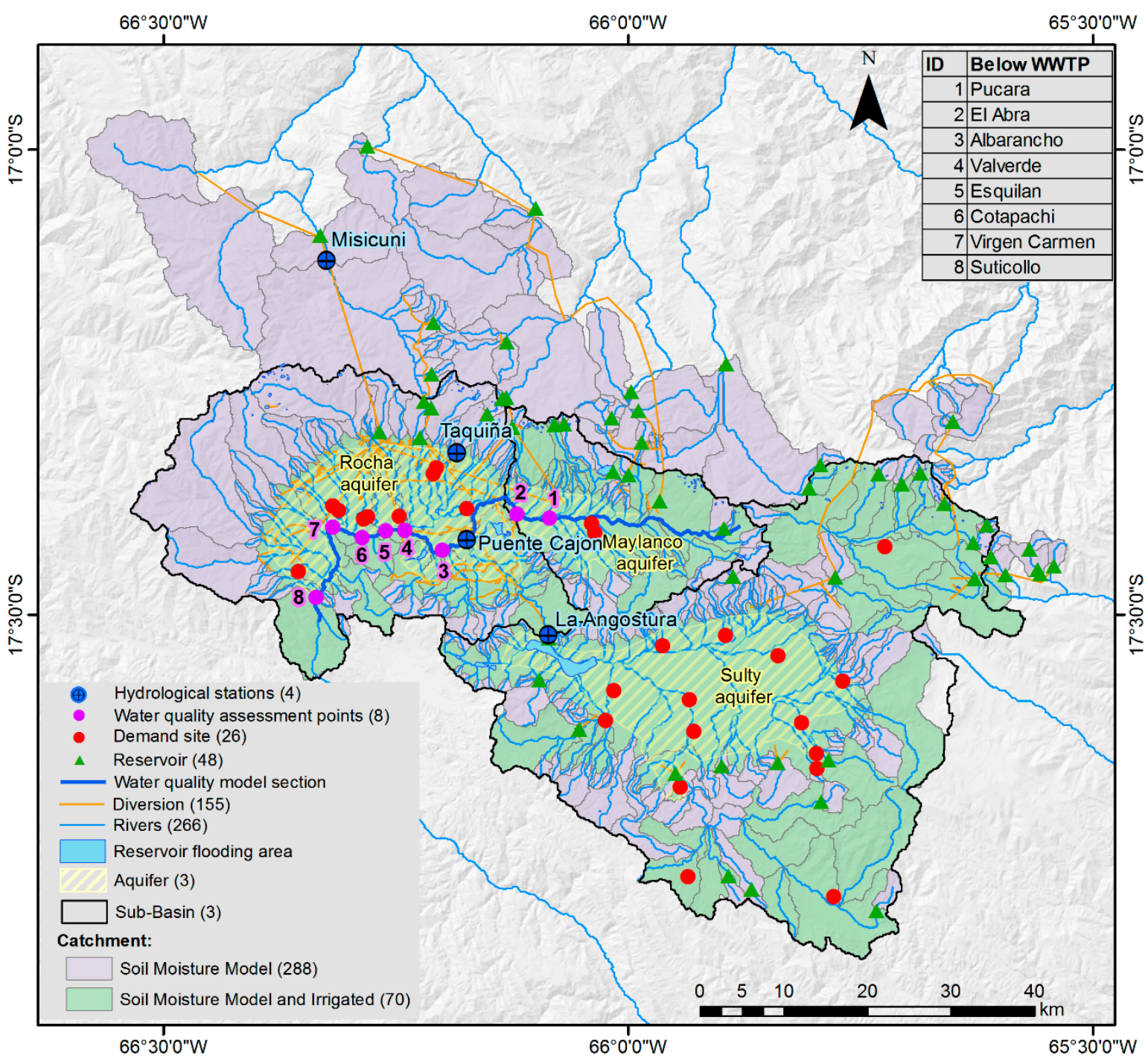

Figure 3. Key components of the Rocha River basin WEAP model. The numbers in parentheses in the legend refer to the number of objects simulated in WEAP.

To determine the irrigation demand and allocation, we calculated the water balance using the Food and Agriculture Organization of the United Nations (FAO) approach, which is based on reference potential evapotranspiration and crop coefficients (Kc) [77]. We defined the irrigation area with the digitalization of high spatial resolution images. We also assimilated information from previous studies to characterize the crop schedule, agricultural calendar, and extent and type of irrigation systems [78-80]. The water balance was implemented at an irrigation zone scale that can include one or several irrigation systems. The catchments that have irrigation are shown in Figure 3. Irrigated zones can cover more than one catchment; for this reason, the total number of modeled zones is 74 , while the number of irrigated catchments is 70 .

For the model calibration, we used the flows measured in Misicuni, Taquiña, and Puente Cajón stations, and the storage levels in La Angostura reservoir (Figure 3). In the drainage area of these stations, the flows are modified by the extractions and storage in reservoirs. Therefore, model calibration is not only limited to optimizing SMM parameters but also to the operation rules and extraction volume. The initial parameters were defined 
with the reference values [81] and then adjusted until an acceptable performance was achieved. At the Misicuni station, a satisfactory Nash-Sutcliffe index of 0.67 and a very good Percent Bias (PBIAS) of $-4.99 \%$ were obtained [82]. The determination coefficient $\left(\mathrm{R}^{2}\right)$ obtained between the modeled and measured storage volumes at La Angostura is 0.76 , which indicates a good performance. The flows measured at Taquiña and Puente Cajón stations are limited. These stations were used to validate the results obtained in La Angostura and Misicuni.

Climate change scenarios in terms of precipitation and temperature for the 2020-2050 future horizon were generated from General Climate Models (GCMs) with downscaling using the non-parametric K-nearest neighbor (K-nn)-Bootstrap statistical method [83]. This modeling process also identified other future uncertainties such as land-use changes and population growth.

\subsection{Participatory Process of Identification and Prioritization of Problems}

The establishment of a formal Inter-Institutional Platform in the Rocha River Basin was a slow process plagued by many challenges. This is due to the large number of municipal jurisdictions in the basin ( 25 in total), the complexity of the problems, and the interests of each territorial level. The Board of Directors and the Technical Council were legally constituted only at the time of identifying intervention actions. The previous steps of the proposed approach involved representatives of municipalities, universities, service providers, and irrigation associations, some of whom became members of the Technical Council. To identify the problems, 15 workshops were organized, which were followed by the collection and assimilation of additional available information on biophysical and sociocultural characteristics, land occupation, hydrological risks, water management, management of life systems, and the institutional framework. The results were presented at a workshop where stakeholders prioritized 11 strategic problems in the basin (Table 1).

Table 1. Problems prioritized by stakeholders in the Rocha River Basin and incorporated in the scoping in WEAP model (shaded in gray).

\section{Prioritized Problems}

\begin{tabular}{lll} 
1. Low coverage for access to safe drinking water & $\begin{array}{l}\text { 7. Vulnerability to hydrological hazards } \\
\text { (flooding, landslides, drought, debris flow) }\end{array}$ \\
$\begin{array}{l}\text { 2. Low coverage in sanitation } \\
\text { 3. Unmet irrigation water demands }\end{array}$ & $\begin{array}{l}\text { 8. Soil salinization } \\
\text { 9. Unsustainable use of groundwater } \\
\text { sustainable productive systems }\end{array}$ & $\begin{array}{l}\text { 10. Institutional weakness to secure equitable } \\
\text { access to water and sustainable river basin } \\
\text { management }\end{array}$ \\
6. Surface and groundwater pollution & $\begin{array}{l}\text { 11. Lack of social awareness about the } \\
\text { importance of water, hydrological cycle and its } \\
\text { relationship with ecosystems and human } \\
\text { activities }\end{array}$ \\
\hline
\end{tabular}

The participatory spaces and the new information helped to scope the development of the WEAP model. For problems related to territorial and terrestrial environmental aspects, spatial analysis was also carried out using Geographic Information System (GIS) and remote sensing methods. The resulting modeling tools contributed to the quantitative characterization of eight of the problems for the historical and future condition representing identified uncertainties in the strategic modeling process [48] (Table 1).

\subsection{Identification of Intervention Actions}

The starting point was the review of the implementation status of current sector plans (e.g., Water and Sanitation Master Plan in the Metropolitan Area), the inventory of 
pre-investment projects of territorial entities, and the coordination with other planning instruments in the process of formulation (e.g., Valle Alto Water Master Plan). In addition, through participatory processes (workshops and meetings with local institutions), new intervention actions were identified in response to the prioritized problems. Table 2 shows the summary of intervention actions to improve conditions associated with water quantity and quality, which can be implemented in the WEAP model. Each has one or more conceptual design options according to its spatial scope, type of technology, and planning level (e.g., pre-feasibility, final design).

Table 2. Summary of intervention actions (L) identified to improve water management in the Rocha River Basin.

\begin{tabular}{|c|c|c|c|}
\hline Sub-Basin & Water Management Intervention & Type of Intervention & Options \\
\hline \multirow{7}{*}{ Rocha and Maylanco } & Misicuni multi-purpose project & Water transfer & 6 \\
\hline & Cordillera Norte multi-purpose project & Water transfer & 3 \\
\hline & Construction of WWTP & Water quality management & 22 \\
\hline & Reducing water losses in urban service areas & Water demand management & 7 \\
\hline & Revitalization of irrigation system & Water demand management & 6 \\
\hline & Technification of irrigation systems & Water demand management & 6 \\
\hline & Top of inactive volume at the La Angostura reservoir & System operation & 4 \\
\hline \multirow{9}{*}{ Sulty } & Khomer Khocha multi-purpose project & Water transfer & 1 \\
\hline & Azul Kocha-Chillahuara & Water transfer & 1 \\
\hline & Encañada reservoir & Water transfer & 1 \\
\hline & Siches reservoir & Infrastructure & 1 \\
\hline & Canllamayu reservoir & Infrastructure & 1 \\
\hline & Kangani reservoir & Infrastructure & 1 \\
\hline & Pucara Mayu reservoir & Infrastructure & 1 \\
\hline & Revitalization of irrigation systems & Water demand management & 15 \\
\hline & Optimization of irrigation systems & Water demand management & 15 \\
\hline \multirow[b]{2}{*}{ All } & Source priority & Water management & \\
\hline & Allocation priority & Water management & \\
\hline
\end{tabular}

The type of actions identified to solve the problem of water scarcity is focused on new water transfers, new reservoirs, and efficiency measures. The water transfers have a multipurpose approach (Misicuni, Cordillera Norte and Khomer Khocha) to supply drinking water, irrigation, and hydropower generation. Due to the complexity of these actions, their implementation is conceived in phases and with different options for their implementation. The number of phases or implementation options are shown in Table 2. In the case of actions referred to the management of irrigation demand, revitalization, and technification, the options refer to the sites of implementation. In the Rocha and Maylanco sub-basin, the six irrigation zones are the options, while in Sulty, there are 15 options. The revitalization consists of improving the current traditional irrigation systems, which includes modernizing the infrastructure (e.g., canals) and irrigation management (operation and maintenance). Technification refers to reducing the demand for water by using technology for the application of irrigation. In terms of water quality management, the options refer to the number of WWTP (11) considered for construction or improvement. In addition, each WWTP has two technology options for a total of 22 options.

\subsection{Design of a Participatory Decision-Making Model (PDM)}

The Participatory Decision-Making Model (PDM) of the basin integrates the WEAP model incorporating uncertainties and intervention actions, and an interactive dashboard that provides user-friendly visualizations to create decision packages and to navigate the resulting performance indicators across the different objectives and levels of disaggregation (Figure 4). The uncertainties implemented in the WEAP model were the climate change scenarios for the IPSL-CM5A-LR model, population growth, and land-use change. The possible intervention actions are summarized in Table 2. The control panel designed in Microsoft Excel facilitated the interaction of the WEAP model with stakeholders. In the 
panel, they could select the intervention actions, uncertainties, water allocation, and the planning horizon (medium-2025, and long term-2040). The selected decisions are sent to the WEAP model through a Microsoft VBA script and then, the model is run. The stakeholders were able to visualize the performance of the intervention measures by means of multi-scale indicators quantified at a range of scales from the basin, sub-basins, microbasins, aquifers, irrigation zones, urban demand units, and river reach. The platform allowed for the visualization of these indicators at the precise scale of interest of each actor. The indicators used are shown in Table 3 where each has the unit of measurement, basic unit of spatial analysis, the upper-level spatial scale, and the function of aggregation. For example, for drinking water, the basic unit of spatial analysis is the urban demand unit, the next level is the sub-basin, and the subsequent level is the basin. The aggregation function depends on the unit of measurement; in the case of volume, the function is the sum. A cost-efficiency indicator was also considered. Multiscale indicators enabled a diverse audience of stakeholders to explore the positive and negative interactions of intervention actions, identify disparities in action performance across scales, and interactively compare different actions that help identify and mitigate emerging regional or sectoral conflicts.

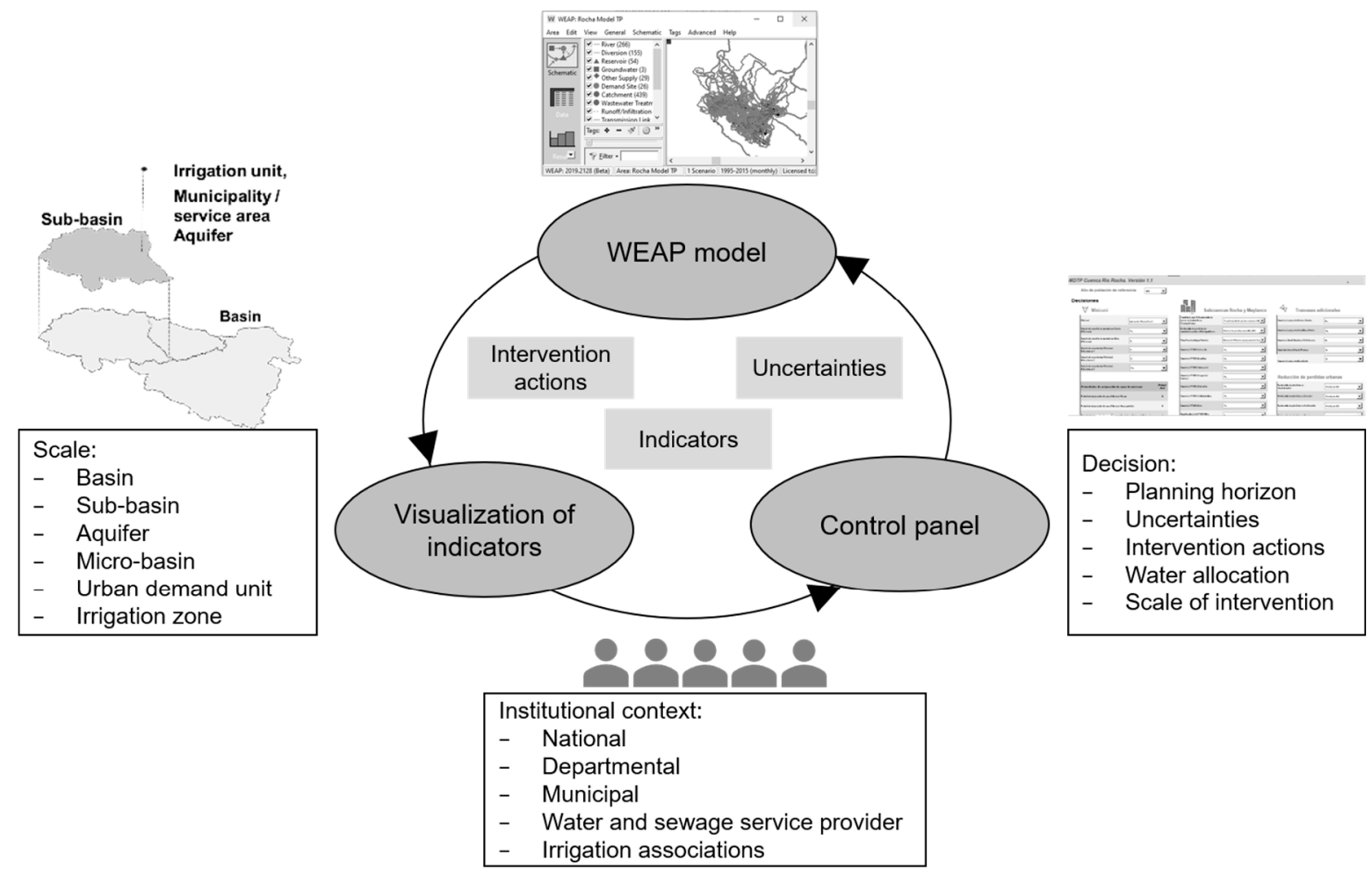

Figure 4. Conceptual design of the participatory decision-making model for the Rocha River Basin.

Table 3. Multiscale indicators (M) to evaluate the performance of intervention actions.

\begin{tabular}{ccccc}
\hline Indicator Name & Unit & Basic Unit of Spatial Analysis $\mathbf{1}^{\mathbf{1}}$ & Aggregation Function & Aggregation Scales $^{2}$ \\
\hline Water demand & $\mathrm{m}^{3} /$ year & Urban demand unit $(26)$ & Sum & Basin (1), sub-basin (3) \\
Coverage & People & Urban demand unit & Sum & Basin, sub-basin \\
Coverage (driest & People & Urban demand unit & Sum & Basin, sub-basin \\
condition) & $\mathrm{m}^{3} /$ year & Urban demand unit & Sum & Basin, sub-basin \\
Unmet demand & $\%$ & Urban demand unit & Weighted average & Basin, sub-basin \\
losses & & &
\end{tabular}


Table 3. Cont.

\begin{tabular}{|c|c|c|c|c|}
\hline Indicator Name & Unit & Basic Unit of Spatial Analysis ${ }^{1}$ & Aggregation Function & Aggregation Scales $^{2}$ \\
\hline $\begin{array}{c}\text { Agricultural areas } \\
\text { under optimal } \\
\text { irrigation }\end{array}$ & Ha & Irrigation zone (74) & Sum & Basin, sub-basin \\
\hline Unmet demand & $\mathrm{m}^{3} /$ year & Irrigation zone & Sum & Basin, sub-basin \\
\hline Recharge & $\mathrm{m}^{3} /$ year & Aquifer (3) & - & - \\
\hline Withdrawal & $\mathrm{m}^{3} /$ year & Aquifer & - & - \\
\hline $\begin{array}{c}\text { Use rate (with- } \\
\text { drawal/recharge) }\end{array}$ & $\%$ & Aquifer & - & - \\
\hline BOD & $\mathrm{mg} / \mathrm{L}$ & Urban river reaches (9) & Weighted average & Rocha River (1) \\
\hline Flow & $\mathrm{L} / \mathrm{s}$ & Urban river reaches & Weighted average & Rocha River Outlet \\
\hline Transfer volume & $\mathrm{Mm}^{3}$ & Sub-basin & Sum & Basin \\
\hline Cost-effectiveness & $\begin{array}{l}\$ / \mathrm{m}^{3} / \text { people } \\
\$ / \mathrm{m}^{3} / \mathrm{ha}\end{array}$ & - & - & - \\
\hline
\end{tabular}

${ }^{1}$ The numbers in parentheses refer to the quantity of basic units. There are 26 urban demand units, 74 irrigation zones, 3 aquifers, and 9 river reaches. ${ }^{2}$ The numbers in parentheses indicate that there is a basin, 3 sub-basins, and a main river.

\subsection{Evaluation of Intervention Actions}

First, each intervention was evaluated individually using the participatory decisionmaking model considering efficiency indicators for different uncertainty scenarios and their performance in the medium (2025) and long term (2040). Second, stakeholders were divided into two groups that through an iterative process identified and prioritized action packages for the time horizons considered and the collection of stakeholder-specific goals (Figure 5). Public institutions such as the MMAyA and different operational institutions of the departmental government (Departmental Watershed Service, and Directorate of Water Management and Basic Services) participated in this process. These institutions work on pre-investment and investment planning related to water (Figure 5). During the group sessions, participants offered four main insights:

- Given the scale and heterogeneity of conflicts over water access, projects currently in development, such as the Misicuni reservoir and water transfer, can provide important-but insufficient-gains toward the plan objectives, with several areas of the basin with high vulnerabilities requiring specific targeted actions.

- Most actions will require additional actions with long-term commitments; mid-term actions must focus on creating the enabling conditions such as pre-investment studies that can last several years accompanied with the search for additional funding sources.

- The solution to water scarcity problems requires large water transfer actions, which may take decades to implement.

- Short-term, efficiency-oriented actions can provide gains toward the required solutions; however, a strategic long-term plan is required to allow a coherent and compatible implementation of short-term and long-term actions. Hence, short-term actions may enable the implementation of middle- and long-term actions and prevent future contradictions among other strategic projects.

During the exercise, not only technical and financial indicators were analyzed but also potential social and environmental conflicts that may make implementation unfeasible. Aspects such as water distribution and allocation priorities were also addressed.

\subsection{Proposal and Approval of the Strategic and Programmatic Framework}

The prioritized actions were organized and structured in lines of action and strategic lines that focused on institutional, sectorial, and community interventions, always considering the principle of the basin approach. The PDC gives action plans that must be pursued in the medium and long term to make substantial progress in the well-being of the inhabitants and their way of life. It also provides an integrated framework to strengthen 
financing processes by coordinating the investments that the territorial authorities make in water management issues, which are currently carried out in a fragmented manner and generate environmental conflicts. Coordination allows for the expansion of the scope of benefits through the coherent use of resources. The PDC document was agreed to by all key stakeholders and approved by the Technical Council. Moreover, the PDC has been declared a departmental law (Decreto Departamental No 4544, 18th of September 2020) [84]. A legal framing means the PDC actions are now binding and must be fulfilled by the sub-basin jurisdictions, hence leveraging financial resources for action implementation and increasing the PDC's visibility across planning scales. Table 4 shows the plan in detail, which has five strategic lines and 82 interventions. The total investment for the period 2020-2040 amounts to USD 1.5 billion; for the current population, this is equivalent to approximately USD 58/person/year. Most of the total investment cost of the plan (98\%) corresponds to the strategic line of water management, which has an implementation horizon of 20 years. For the first five years (planning horizon of the PDC), priority was given to the construction and improvement of the WWTP, the construction of water conduction infrastructure of the Misicuni, starting with detailed pre-investment studies for new water transfers (Cordillera Norte and Khomer Khocha), water demand management, and preservation of the drainage area of current and potential transfer basins (water reserve zone). The 2026-2040 horizon of the plan contemplates the construction and putting in operation of the new water transfers, the extension of the water distribution network and sanitary sewerage, and the new WWTP. With this package of actions in the medium term (2025), progress will be made in improving the quality of water in the Rocha River and reducing unsatisfied demand in the Rocha and Maylanco sub-basins. The solution to water scarcity problems in the entire basin depends mostly on new water transfers, which will require decades to implement. The other strategic lines have an implementation horizon in accordance with the times established in the national basin policy. These lines seek to improve the sustainable management of micro-basins, institutional strengthening for water resources management, improving information and knowledge, and water culture. The baseline and plan indicators agreed upon for the 2020 and 2040 horizons are described in detail below. The baseline is the current system of water resource management projected for different future time horizons.

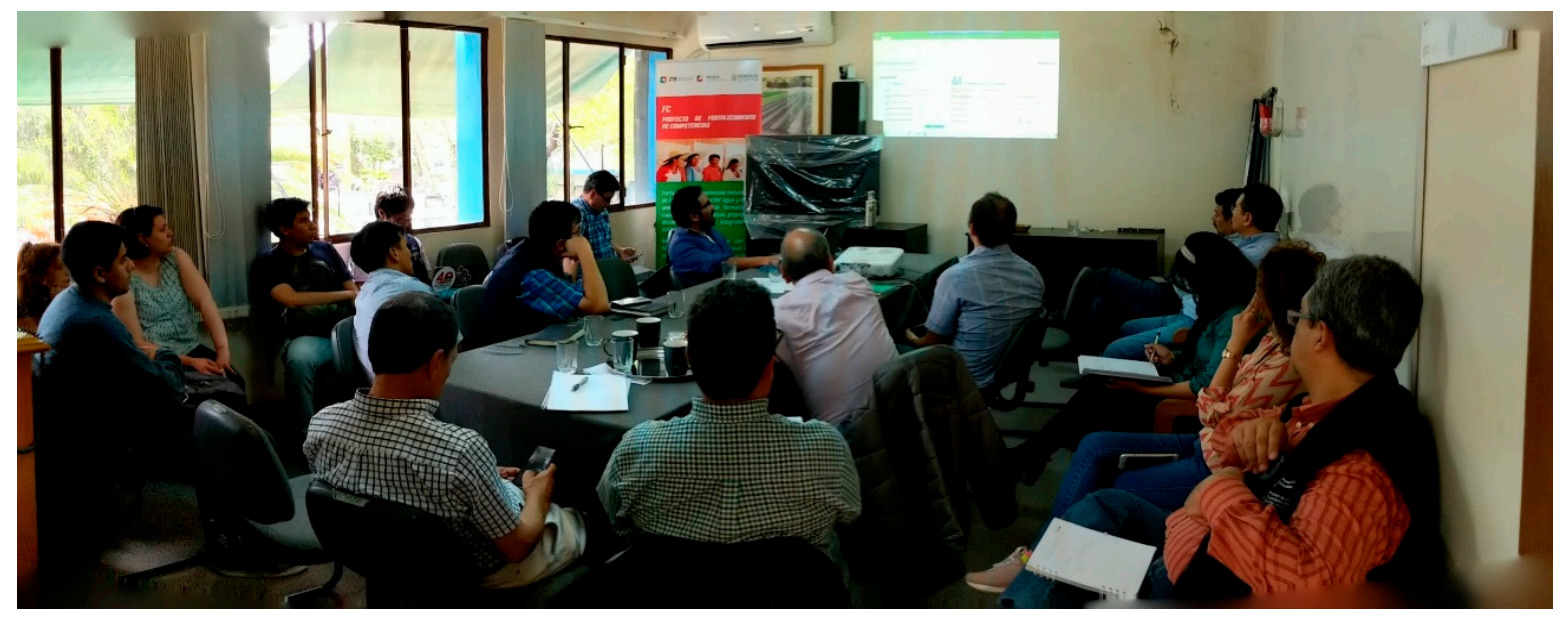

Figure 5. Photograph of the workshop for the evaluation of medium- (2025) and long-term (2040) intervention actions using the participatory decision-making model. 
Table 4. Summary of the Rocha River Basin master plan agreed with the Inter-Institutional Platform.

\begin{tabular}{|c|c|c|c|c|}
\hline Strategic Line & Number of Actions & Horizon & Key Actions & $\begin{array}{c}\text { Investment } \\
\text { (USD) }^{1}\end{array}$ \\
\hline \multirow[t]{2}{*}{ Water management } & \multirow[t]{2}{*}{37} & 2025 & $\begin{array}{ll}\text { - } & \text { Infrastructure for the conduction and distribution of drinking water and irrigation (Misicuni). } \\
\text { - } & \text { Construction of WWTP in the Rocha sub-basin and expansion of sewerage coverage. } \\
\text { - } & \text { Pre-investment studies of strategic actions for new water transfer. } \\
\text { - } & \text { Water demand management actions in urban areas and irrigation areas. } \\
\text { - } & \text { Adoption of strategic micro-basins as water reserves to prevent the emergence of land-use conflicts. }\end{array}$ & $532.8 \mathrm{M}$ \\
\hline & & $2026-2040$ & $\begin{array}{ll}\text { - } & \text { Construction and operation of new water transfer infrastructure. } \\
\text { - } & \text { Expansion of water distribution network coverage in urban areas and irrigation. } \\
\text { - } & \text { Extension of sanitary sewerage coverage and new WWTPs in the Sulty sub-basin. }\end{array}$ & $958.4 \mathrm{M}$ \\
\hline $\begin{array}{l}\text { Integral and sustainable } \\
\text { management of sub-basin } \\
\text { and micro-basin }\end{array}$ & 19 & 2025 & $\begin{array}{l}\text { - } \quad \text { Mitigation of soil erosion, landslides, loss of vegetation cover, and flood risk. } \\
\text { - } \quad \text { Protection of aquifer recharge areas and management of saline soils. } \\
\text { Restoration of environmental functions of water regulation through afforestation, reforestation, and the } \\
\text { recovery of native grasslands. } \\
\text { Incorporate the watershed approach in territorial planning and management of hydrological risks on a basin } \\
\text { scale through preventive and mitigating actions. }\end{array}$ & $20.8 \mathrm{M}$ \\
\hline $\begin{array}{l}\text { Institutional } \\
\text { strengthening }\end{array}$ & 10 & 2025 & $\begin{array}{l}\text { - The operational consolidation of the Inter-Institutional Platform and strengthening and formation of Strategic } \\
\text { - } \quad \text { Assigning normative hierarchy to the plan through a departmental law or ministerial resolution. } \\
\text { - } \quad \text { The promotion of the plan to generate knowledge and institutional commitment } \\
\text { - } \quad \text { Institutional strengthening of territorial entities in water management. } \\
\text { - Identification of institutional mechanisms for conflict resolution. }\end{array}$ & $2.4 \mathrm{M}$ \\
\hline Water culture & 8 & 2025 & $\begin{array}{l}\text { Promote environmental sustainability before institutions and citizens through actions such as art, competitive } \\
\text { funds, exchange of experiences, spaces for reflection and recreation, academic research, and design of tourist } \\
\text { routes. }\end{array}$ & $3.3 \mathrm{M}$ \\
\hline
\end{tabular}

${ }^{1}$ Conversion rate: 1 USD $=6.96$ BOB (reference year 2019). 


\subsubsection{Baseline Indicators}

Projections until 2025 and 2040 indicate that the basin would have a population of $1,518,502$ and 2,228,632 people, respectively. The irrigable area is approximately 40,002 ha, which was assumed to be constant for future time horizons. Performance indicators up to 2025 (Table 5) indicate that the current supply system could supply only $66 \%$ of the population and optimally irrigate 19,443 ha. The annual volume of unsatisfied demand in the basin would be $340.3 \mathrm{Mm}^{3}$. The water quality in the Rocha River modeled by BOD would be $153 \mathrm{mg} / \mathrm{L}$, which is approximately four times higher than the limits established in national legislation. The Sulty sub-basin would have an unsustainable exploitation of groundwater. By 2040, these indicators could worsen (see Table 5); for example, the unsatisfied demand could reach $362.7 \mathrm{Mm}^{3}$. The current supply system would only have the capacity to supply $59 \%$ of the population, and irrigation conditions would remain similar to those encountered in the medium term.

\subsubsection{Indicators of the Agreed Plan}

In this paper, we present the aggregated results at the basin and sub-basin scale; however, in the PDM, the results can be visualized at the basic service area unit scale of modeling. Table 5 shows the expected level of improvement in the main performance indicators up to 2025 (medium term). The plan expects to reduce the annual unmet demand in the basin by $64.9 \mathrm{Mm}^{3}$. The population benefited by the package of actions is 403,647 people. In irrigation, it is expected that the deficit will be reduced by $58.1 \mathrm{Mm}^{3}$ and the optimal irrigated area will increase by 1768 ha. In water quality, a reduction of BOD by $101 \mathrm{mg} / \mathrm{L}$ is expected-that is, a reduction of more than 70\% of the current levels of contamination, and at the same time, an increase of approximately $20 \%$ in the flow during the low water season to improve the environmental functionality and the assimilation capacity of the Rocha River.

Table 5 shows the indicators expected in the long term (2040). The package of actions will reduce unsatisfied water demand by $227 \mathrm{Mm}^{3}$ in the basin, thus increasing access to safe water by 834,049 people and increasing the area under optimal irrigation by 10,497 ha. The increase in the supply of surface water will make it possible to achieve the sustainable use of all the aquifers in the basin - that is, by exploiting them within the limits of their natural recharge. In terms of water quality, a reduction in BOD of $125 \mathrm{mg} / \mathrm{L}$ is expected as well as an increase in the flow of the River Rocha in the months of low water by $359 \mathrm{~L} / \mathrm{s}$.

In the Maylanco sub-basin, indicators presented negative changes up until the year 2025. For example, drinking water coverage reduced by 3759 people, and unmet demand increased by $0.4 \mathrm{Mm}^{3}$ (Table 5). This is mainly due to the expansion of the water distribution system from Misicuni to the municipalities of the Rocha sub-basin. In the baseline scenario, the Maylanco sub-basin would be benefitted from higher water volumes; however, the proposed plan will reduce the water volumes given the expansion of the water distribution system. These changes are also reflected in the increase of the groundwater use rate by $52 \%$. In the Pucara and Abra sections (Maylanco sub-basin), there is a small BOD increase due to the reduction in volumes delivered from Misicuni, which also reduces the river's self-purification capacity. 
Table 5. Performance of the proposed actions (2025 and 2040).

\begin{tabular}{|c|c|c|c|c|c|c|c|c|c|c|c|c|c|c|c|c|}
\hline \multirow{2}{*}{ Component } & \multirow{2}{*}{ Indicator } & \multirow{2}{*}{ Unit } & \multirow{2}{*}{\multicolumn{2}{|c|}{ Spatial Domain }} & \multicolumn{4}{|c|}{ Base Line } & \multicolumn{4}{|c|}{ Agreed Plan } & \multicolumn{4}{|c|}{ Expected Change } \\
\hline & & & & & \multicolumn{2}{|c|}{2025} & \multicolumn{2}{|c|}{2040} & \multicolumn{2}{|c|}{2025} & \multicolumn{2}{|c|}{2040} & \multicolumn{2}{|c|}{2025} & \multicolumn{2}{|c|}{2040} \\
\hline \multirow{6}{*}{ Drinking water } & \multirow{3}{*}{ Coverage } & \multirow{3}{*}{ People } & \multirow[b]{2}{*}{ Sub-basin } & Sulty & \multicolumn{2}{|c|}{66,733} & \multicolumn{2}{|c|}{87,171} & \multicolumn{2}{|c|}{66,733} & \multicolumn{2}{|c|}{148,232} & \multicolumn{2}{|c|}{0} & \multicolumn{2}{|c|}{61,061} \\
\hline & & & & $\begin{array}{c}\text { Rocha } \\
\text { Maylanco }\end{array}$ & \multicolumn{2}{|c|}{$\begin{array}{l}715,953 \\
222,569\end{array}$} & \multicolumn{2}{|c|}{$\begin{array}{l}853,199 \\
372,068\end{array}$} & \multicolumn{2}{|c|}{$\begin{array}{c}1,123,359 \\
218,810\end{array}$} & & $\begin{array}{l}808 \\
448\end{array}$ & $\begin{array}{r}407 \\
-3\end{array}$ & & $\begin{array}{r}75 \\
13\end{array}$ & \\
\hline & & & & & 1,0 & 254 & & 438 & & 901 & & 487 & 403 & & 83 & \\
\hline & & & & Sulty & & & & & & & & & 0 & & & \\
\hline & Th & $x^{3}+2+3$ & Sub-basin & Rocha & & & & & & & & & - & & & \\
\hline & & & & & & & & & & & & & -6 & & & \\
\hline & & & & Sulty & & & & & & & & & 7 & & & \\
\hline & Optimal irrigation & & Sub-basin & Rocha & & & & & & & & & 9 & & & \\
\hline & area & ha & & Maylanco & & & & & & & & & 1 & & & \\
\hline Irrigation & & & & & & & & & & & & & 17 & & & \\
\hline & & & & Sulty & & & & & & & & & -2 & & & \\
\hline & & & Sub-basin & Rocha & & & & & & & & & -2 & & & \\
\hline & Unmet demand & $\mathrm{Mm}^{3}$ & Suv-dasint & Maylanco & & & & & & & & & - & & & \\
\hline & & & & Pucara & 38 & 213 & 53 & 266 & 39 & 210 & 49 & 282 & 1 & -3 & -4 & 16 \\
\hline & & & & Abra & 59 & 437 & 73 & 613 & 61 & 422 & 66 & 660 & 3 & -15 & -7 & 47 \\
\hline & & & & Albarancho & 123 & 277 & 138 & 469 & 46 & 483 & 49 & 876 & -76 & 207 & -89 & 407 \\
\hline & & & & Valverde & 105 & 277 & 117 & 469 & 64 & 483 & 56 & 876 & -41 & 207 & -61 & 407 \\
\hline Water quality & BOD, Flow & $\mathrm{mg} / \mathrm{L}, \mathrm{L} / \mathrm{s}$ & River reach & Esquilan & 196 & 606 & 207 & 840 & 60 & 581 & 53 & 1003 & -136 & -25 & -154 & 164 \\
\hline & & & & Cotapachi & 198 & 614 & 209 & 848 & 61 & 800 & 55 & 1334 & -137 & 186 & -155 & 486 \\
\hline & & & & Virgen Carmen & 268 & 710 & 312 & 944 & 57 & 872 & 53 & 1485 & -211 & 161 & -258 & 541 \\
\hline & & & & Suticollo & 185 & 568 & 220 & 802 & 36 & 753 & 35 & 1446 & -149 & 184 & -184 & 644 \\
\hline & & & & iver & 153 & 502 & 177 & 703 & 52 & 613 & 52 & 1062 & -101 & 111 & -125 & 359 \\
\hline & & & & Sulty & & & & & & & & & & & & \\
\hline Groundwater & Use rate & $\%$ & Aquifer & Rocha & & & & & & & & & - & & & \\
\hline & & & & Maylanco & & & & & & & & & 5 & & & \\
\hline
\end{tabular}


Cost-effectiveness analysis was part of the performance indicators used in the process of evaluating intervention actions. Some sector interventions identified before the formulation of the PDC presented unfavorable values in terms of cost-effectiveness, especially water transfers such as Khomer Khocha. The intervention assessment process explored options to make interventions feasible within the framework of the basin planning. The multipurpose approach of the actions has been an option that allowed obtaining more encouraging indicators of economic efficiency. Table 6 shows the cost-effectiveness indicators of the agreed plan for the different time horizons. In the case of drinking water, the highest value is related to the implementation of the Misicuni additional water transfers. In irrigation, the indicators are well within the Bolivian viability threshold of 10,000 USD/ha. The highest value in the horizon 2035 is related to the implementation of the Khomer Khocha water transfer that benefits mainly irrigation in the Sulty.

Table 6. Cost-effectiveness indicators of the agreed plan for water supply actions for drinking water and irrigation.

\begin{tabular}{ccccc}
\hline \multirow{2}{*}{ Horizon } & \multicolumn{2}{c}{ Drinking Water } & \multicolumn{2}{c}{ Irrigation } \\
\cline { 2 - 5 } & USD/People & Thousands USD/Mm & USD/ha & Thousands USD/Mm \\
\hline 2025 & 6 & 377 & 2370 & 72 \\
2030 & 20 & 782 & 1764 & 82 \\
2035 & 6 & 179 & 4507 & 246 \\
2040 & 0.2 & 6 & 858 & 46 \\
\hline
\end{tabular}

\section{Discussion}

4.1. How Does the Water Resources System Model Respond to Water-Related Decision-Making Processes and Institutional Governance Design at a Range of Scales within a River Basin?

In the Rocha River Basin, all available water is in use, which means that there is no free water for new uses [85], and management decisions are fundamentally a redistribution between existing users. According to the modeling, the demand for water is potentially three times the natural availability of the basin; hence, there is extensive unsafe reuse and a growing dependence on external sources. The implementation or intervention actions that consider expanding the use of the basin's supply sources generate conflicts. In this context, the formulation of the basin plan faced many challenges. In the decisionmaking process, analytical modeling tools helped to recognize, quantify, and differentiate the local and regional impacts of water reallocation. Our multiscale approach allowed the diverse frames of reference of basin stakeholders such as small OLPES, individual irrigation zones, and municipal jurisdictions to identify their interdependence with other sector-specific goals or regions, including those operating at different scales, and engage in productive negotiations.

An example to illustrate this is the Siches Reservoir (Table 7), which in the Sulty sub-basin generates an incremental irrigation area of 797 ha, but in the Rocha sub-basin, the optimal irrigation area is reduced by $222 \mathrm{ha}$. The drainage area of this potential reservoir is one of the main tributaries to the La Angostura reservoir, which in turn supplies irrigation areas in the Rocha sub-basin. To compensate for the conflicts identified, iterative exercises (as shown in Figure 3) were carried out. These exercises contributed to the construction of a package of actions to achieve the full spectrum of objectives and goals (Table 7). In addition, it was possible to incorporate climate change into decision making with the model. In the process of building the action set, stakeholders were able to visualize results of how climate change in the long term could lead to problems in the reliability of water supply systems. This is how actions to build resilience in water supply systems were assessed. Based on this exercise, the new Cordillera Norte water transfer action was formulated as part of the plan. 
Table 7. Performance in irrigation of the intervention action of Siches Reservoir.

\begin{tabular}{cccc}
\hline \multirow{2}{*}{ Sub-Basin } & \multicolumn{3}{c}{ Optimal Irrigation Area [ha] } \\
\cline { 2 - 4 } & Base Line & Intervention Action & Change \\
\hline Sulty & 12,042 & 12,839 & 797 \\
Rocha & 6411 & 6189 & -222 \\
Maylanco & 990 & 990 & 0 \\
Basin & 19,443 & 20,018 & 575 \\
\hline
\end{tabular}

Likewise, the results of the model showed that water-use efficiency actions and expansion of current supply sources in the basin, while providing important gains in performance, cannot compensate for existing conflicts on their own or fulfill the medium- and long-term PDC main goals, such as universal and equitable access to safe water. Therefore, solutions to scarcity problems will also require several strategic actions that increase the volume of water transfers. Due to the multipurpose nature and regional scope, it will also allow substantial progress in the sustainable use of groundwater by supplementing current wells with transferred surface water. By improving the environmental conditions of the rivers, it will also provide greater capacity for assimilation by increasing the flow in months of low water from the return flows.

The analytical tool for decision-making in the basin makes it possible to co-develop strategies in participatory spaces with the interested parties. The use of models in conflict management is recognized in the scientific literature [86,87]. However, formalizing their use in decision-making within the framework of the basin plan had many challenges related to limited data, the complexity of traditional water management, the spatial and temporal scale of water supply systems, and some resistance to the use of models. At the beginning of the process, the main challenge was the lack of credibility for the use of the model in formulating the plan, as stakeholders indicated that the available data were insufficient to develop the watershed WEAP model. In addition, incorporating the model into planning meant adjusting the PDC's methodological guidelines, which also generated resistance in certain government institutions. To address these challenges, partnerships were formed with local universities to maximize the use of available data and advances, intensive fieldwork to collect irrigation data, discussion meetings with local experts, and workshops to share the inputs and results. The participatory modeling approach generated opportunities to iterate the process while interacting with local experts. By involving stakeholders early in the process, we were able to make adjustments and continuous improvement in the formulation of the river basin plan. As mentioned by Loucks et al. [45], the credibility of a model is very subjective, and the modeling, besides trying to represent reality, is also an attempt to formalize and guide those perceptions.

It is important to recognize that there are conflicts around intervention actions that cannot be negotiated through the support of models because they require arrangements in traditional, sectoral, institutional, and legal use rights. For example, water transfer actions generate conflicts in the territory of new uses [55]. Based on experiences of the Misicuni water transfer, this type of action generates the displacement of rural community settlements, the loss of productive land, and the drying up of wetlands and springs [51] with unjust compensation $[88,89]$. With these precedents, the transfer actions proposed in the watershed plan could face similar conflicts.

\subsection{How Does the Water Resources System Model Contribute to the Development of Effective Water Planning Instruments?}

Formulating and implementing river basin master plans in Bolivia is a learning process built on experiences from strategic basins of varied geographic contexts. For instance, the first master plan of the Rocha River Basin showed progress in elaborating the diagnostic study and the strategic guidelines. It also made progress in the implementation of IRBM actions in priority micro-basins and flood mitigation infrastructure. Its water management strategy focused on water access and use. However, it was up to sectorial plans (e.g., the 
Water Master Plan) to identify the actions needed to fulfill the master plan. The initial strategy lacked quantitative indicators and goals in its implementation horizon, which would have enabled monitoring and follow-up processes as well as connections with other plans at the national scale. For instance, the Bolivian Economic and Social Development Plan could have been a potential connection, since 'achieving universal access to water' is also one of its objectives. Since the formulation of the first basin plan, the Rocha and Maylanco sub-basins made significant progress with their Water and Sanitation Master Plan. However, the proposed actions were not aligned with other water uses, such as irrigation, since the Water and Sanitation Master Plan focused on water for human consumption. Lastly, the Sulty sub-basin made progress in managing financial sources for the preparation of the Water Master Plan.

The updating of the Basin Plan under the proposed approach was an opportunity to coordinate these sectoral interventions and the actions promoted from the different territorial entities that are not necessarily connected to objectives at the regional- and basin-level. In addition, the updated plan has a sequence of short-, medium-, and long-term actions, thus recognizing the potential effects of climate change. Its strategic and multisectoral approach made it possible to identify a wide range of co-benefits and compensation measures. The flexibility of the analytical decision-making tool will allow monitoring and follow-up as the plan is implemented, and if necessary, the goals could be adjusted according to new orientations in policy or new stakeholder priorities.

\section{Conclusions}

Our integrated approach lays the foundation to apply the RDS framework in water resources management, building upon and expanding on Bolivia's basin policy. The formulation of the River Rocha PDC led to formalizing the use of modeling tools in the context of river basin planning in Bolivia. However, we faced many challenges arising from the planning process to identify strategic actions, particularly those related to expanding the use of the basin's supply sources. We connected sector- and territorial-based actions across the river basin while engaging municipalities and the regional and national governments in the planning process. Our analytical modeling tools helped to identify and quantify the trade-offs between local and regional impacts that a new water use could generate, hence facilitating the decision-making process. Once we identified positive and negative effects of the proposed actions, the participants could negotiate and propose compensation measures within the PDC. We formulated a PDC considering short-, medium-, and long-term climate change scenarios, setting out measurable goals for each time horizon and establishing implementation phases for the proposed actions. Our iterative RDS process allowed for re-arrangements or changes within the water resources system modeling according to the stakeholders' inputs and needs.

The PDC covers a wide range of topics-from flood control measures to determining a financial plan for the implementation of strategic actions. As previously mentioned, the analytical tools are key to the river basin planning process. However, not all territorialbased actions are integrated in the water resources system model. Further research is needed to integrate territorial-based actions and water resources modeling for participatory decision-making process, hence minimizing potential conflicts in planning instruments such as the PDC. In addition, water resources system models alone may not recognize all water-related conflicts. Water resources modeling tools may be limited in their capacity to propose sound socioeconomic alternatives and/or compensations to people directly or indirectly affected by water-related projects. Although our water resources system model accommodated water volumes according to each implemented action in the river basin, our work has not directly addressed legal and institutional conflicts behind those actions. In addition to indicating the water availability through a detailed water budget, anticipating conflicts that might emerge in the strategy implementation phase could help with conflict management under scenarios of uncertainty. Moreover, the Andean region of Bolivia widely adopts usos y costumbres to ensure water rights in communal territories. 
The Cochabamba Valley is no exception to these historical customary practices. As properly observed by Hendriks [65], "water belongs to the territory and the territory belongs to the community". Further research is needed to intentionally intersect planning at the river basin level with water management in communal territories, addressing any mismatching policies that may escalate potentially divisive water governance approaches.

The RDS approach applied in the Bolivian context may facilitate IWRM implementation at the river basin scale by providing both rigorous water resources system modeling and effective stakeholder participation. Our proposed framework creates an opportunity for stakeholders to engage in the water management process and highlights the need of ensuring participatory processes to legitimate planning instruments for the river basin. We are comfortable that the approach taken addresses the general challenges facing IWRM and the specific context of water management in Bolivia. The key was allowing for cross-scale evaluation of the performance of different actions and a direct integration of watershed and water resources management interventions.

Author Contributions: Conceptualization, N.L.-Q., C.C. and H.A.; methodology, N.L.-Q., W.R., Z.G. and H.A.; software, N.L.-Q. and H.A.; validation, N.L.-Q., C.C. and H.A.; formal analysis, N.L.-Q., Z.G., F.Z., S.N., J.I. and H.A.; investigation, N.L.-Q., W.R., Z.G., F.Z., S.N., J.I., C.S. and H.A.; resources, N.L.-Q., D.P., M.E. and H.A.; data curation, N.L.-Q., F.Z., S.N., J.I. and C.S.; writingoriginal draft preparation, N.L.-Q., C.C., D.P. and H.A.; writing-review and editing, C.C., D.P. and H.A.; visualization, N.L.-Q., J.I. and H.A.; supervision, H.A.; project administration, D.P.; funding acquisition, D.P. and M.E. All authors have read and agreed to the published version of the manuscript.

Funding: The "Pilot Program for Climate Resilience-Ministry of Environment and Water, Bolivia, grant number 01/2018" funded the formulation of the River Rocha PDC and the "Stockholm Environment Institute's Regional Engagement Funds" financed the preparation of the manuscript.

Institutional Review Board Statement: Not applicable.

Informed Consent Statement: Not applicable.

Data Availability Statement: Not applicable.

Acknowledgments: We gratefully acknowledge the support of the Pilot Program for Climate Resilience-Ministry of Environment and Water (PPCR-MMAyA), the World Bank office in La Paz, and the Secretaría Departamental de los Derechos de la Madre Tierra (including the Servicio Departamental de Cuencas and the Dirección de Gestión de Agua y Servicios Básicos). We would also like to acknowledge the support of some SEI consultants and the PPCR supervision team who assisted in the implementation of the proposed approach.

Conflicts of Interest: The authors declare no conflict of interest.

\section{References}

1. Lemos, M.C.; Kirchhoff, C. Climate Information and Water Management. In The Oxford Handbook of Water Politics and Policy; Conca, K., Weinthal, E., Eds.; Oxford University Press: Oxford, UK, 2016; Volume 1.

2. Hoegh-Guldberg, O.; Jacob, D.; Taylor, M.; Bindi, S.; Brown, I.; Camilloni, A.; Diedhiou, A.; Djalante, R.; Ebi, K.; Engelbrecht, J.; et al. Impacts of $1.5^{\circ} \mathrm{C}$ Global Warming on Natural and Human Systems; Global Warming of $1.5^{\circ} \mathrm{C}$. An IPCC Special Report on the impacts of global warming of $1.5^{\circ} \mathrm{C}$ above pre-industrial levels and related global greenhouse gas emission pathways, in the context of strengthening the global response to the threat of climate change, sustainable development, and efforts to eradicate poverty; IPCC: Geneva, Switzerland, 2018.

3. Hall, J.W.; Grey, D.; Garrick, D.; Fung, F.; Brown, C.; Dadson, S.J.; Sadoff, C.W. Coping with the curse of freshwater variability. Science 2014, 346, 429-430. [CrossRef] [PubMed]

4. Hall, J.W.; Borgomeo, E.; Mortazavi-Naeini, M.; Wheeler, K. Water Resource System Modelling and Decision Analysis. In Water Science, Policy, and Management; Dadson, S.J., Garrick, D.E., Penning-Rowsell, E.C., Hall, J.W., Hope, R., Hughes, J., Eds.; John Wiley \& Sons: Hoboken, NJ, USA, 2019; pp. 257-273. ISBN 978-1-119-52060-3.

5. Pahl-Wostl, C. A conceptual framework for analysing adaptive capacity and multi-level learning processes in resource governance regimes. Glob. Environ. Chang. 2009, 19, 354-365. [CrossRef]

6. Jiménez, A.; Saikia, P.; Giné, R.; Avello, P.; Leten, J.; Liss Lymer, B.; Schneider, K.; Ward, R. Unpacking Water Governance: A Framework for Practitioners. Water 2020, 12, 827. [CrossRef] 
7. Unatide Nations World Water Assessment Programme. Water for People, Water for Life; The United Nations World Water Development Report: Executive Summary; UNESCO Publishing: Paris, France, 2003.

8. Lubell, M.; Balazs, C. Integrated Water Resources Management. In The Oxford Handbook of Water Politics and Policy; Conca, K., Weinthal, E., Eds.; Oxford University Press: Oxford, UK, 2016; Volume 1.

9. Global Water Partnership Integrated Water Resources Management; TAC Background Papers; Global Water Partnership: Stockholm, Sweden, 2000.

10. Rahaman, M.M.; Varis, O. Integrated water resources management: Evolution, prospects and future challenges. Sustain. Sci. Pract. Policy 2005, 1, 15-21. [CrossRef]

11. Transforming our World: The 2030 Agenda for Sustainable Development. Available online: https://sdgs.un.org/2030agenda (accessed on 10 October 2020).

12. United Nations. Sustainable Development Goal 6 Synthesis Report 2018 on Water and Sanitation; United Nations Publications: New York, NY, USA, 2018.

13. Lautze, J.; de Silva, S.; Giordano, M.; Sanford, L. Putting the cart before the horse: Water governance and IWRM. Nat. Resour. Forum 2011, 35, 1-8. [CrossRef]

14. Neto, S.; Camkin, J.; Fenemor, A.; Tan, P.-L.; Baptista, J.M.; Ribeiro, M.; Schulze, R.; Stuart-Hill, S.; Spray, C.; Elfithri, R. OECD Principles on Water Governance in practice: An assessment of existing frameworks in Europe, Asia-Pacific, Africa and South America. Water Int. 2018, 43, 60-89. [CrossRef]

15. Molle, F. River Basin Management and Development. In International Encyclopedia of Geography: People, the Earth, Environment and Technology; Richardson, D., Castree, N., Goodchild, M.F., Kobayashi, A., Liu, W., Marston, R.A., Eds.; John Wiley \& Sons: Oxford, UK, 2017; pp. 1-12. ISBN 978-0-470-65963-2.

16. Kauffman, G.J. Governance, Policy, and Economics of Intergovernmental River Basin Management. Water Resour. Manag. 2015, 29, 5689-5712. [CrossRef]

17. Gerlak, A.K.; Schmeier, S. River Basin Organizations and the Governance of Transboundary Watercourses. In The Oxford Handbook of Water Politics and Policy; Conca, K., Weinthal, E., Eds.; Oxford University Press: Oxford, UK, 2016; Volume 1.

18. Colon, M.; Richard, S.; Roche, P.-A. The evolution of water governance in France from the 1960s: Disputes as major drivers for radical changes within a consensual framework. Water Int. 2018, 43, 109-132. [CrossRef]

19. Newson, M. Land, Water and Development: Sustainable and Adaptive Management of Rivers; Routledge: Abingdon, UK, 2008; ISBN 1-134-11190-8.

20. Pereira, H.C. Policy and Practice in the Management of Tropical Watersheds; Routledge: Abingdon, UK, 2019; ISBN 1-00-030613-5.

21. Blomquist, W.; Schlager, E. Political Pitfalls of Integrated Watershed Management. Soc. Nat. Resour. 2005, 18, 101-117. [CrossRef]

22. Warner, J.; Wester, P.; Bolding, A. Going with the flow: River basins as the natural units for water management? Water Policy 2008, 10, 121-138. [CrossRef]

23. Poteete, A.R.; Janssen, M.; Ostrom, E. Working Together: Collective Action, the Commons, and Multiple Methods in PRACTICE; Princeton University Press: Princeton, NJ, USA, 2010; ISBN 978-0-691-14603-4.

24. Vörösmarty, C.J.; Pahl-Wostl, C.; Bunn, S.E.; Lawford, R. Global water, the anthropocene and the transformation of a science. Curr. Opin. Environ. Sustain. 2013, 5, 539-550. [CrossRef]

25. Baldwin, E.; McCord, P.; Dell'Angelo, J.; Evans, T. Collective action in a polycentric water governance system. Environ. Policy Gov. 2018, 28, 212-222. [CrossRef]

26. Mashaly, A.F.; Fernald, A.G. Identifying Capabilities and Potentials of System Dynamics in Hydrology and Water Resources as a Promising Modeling Approach for Water Management. Water 2020, 12, 1432. [CrossRef]

27. Mirchi, A.; Madani, K.; Watkins, D., Jr.; Ahmad, S. Synthesis of System Dynamics Tools for Holistic Conceptualization of Water Resources Problems. Water Resour. Manag. 2012, 26, 2421-2442. [CrossRef]

28. Halbe, J.; Pahl-Wostl, C.; Adamowski, J. A methodological framework to support the initiation, design and institutionalization of participatory modeling processes in water resources management. J. Hydrol. 2018, 556, 701-716. [CrossRef]

29. Freas, K.; Bailey, B.; Munévar, A.; Butler, S. Incorporating climate change in water planning. J. AWWA 2008, 100, 92-99. [CrossRef]

30. Anderson, J.; Chung, F.; Anderson, M.; Brekke, L.; Easton, D.; Ejeta, M.; Peterson, R.; Snyder, R. Progress on incorporating climate change into management of California's water resources. Clim. Chang. 2008, 87, 91-108. [CrossRef]

31. Groves, C.R.; Game, E.T.; Anderson, M.G.; Cross, M.; Enquist, C.; Ferdaña, Z.; Girvetz, E.; Gondor, A.; Hall, K.R.; Higgins, J.; et al. Incorporating climate change into systematic conservation planning. Biodivers. Conserv. 2012, 21, 1651-1671. [CrossRef]

32. Bonelli, S.; Vicuña, S.; Meza, F.J.; Gironás, J.; Barton, J. Incorporating climate change adaptation strategies in urban water supply planning: The case of central Chile. J. Water Clim. Chang. 2014, 5, 357-376. [CrossRef]

33. Leavesley, G.H. Modeling the Effects of Climate Change on Water resources-A Review. In Assessing the Impacts of Climate Change on Natural Resource Systems; Frederick, K.D., Rosenberg, N.J., Eds.; Springer: Dordrecht, The Netherlands, $1994 ;$ pp. $159-177$. ISBN 978-94-011-0207-0.

34. Abbaspour, K.C.; Faramarzi, M.; Ghasemi, S.S.; Yang, H. Assessing the impact of climate change on water resources in Iran. Water Resour. Res. 2009, 45. [CrossRef]

35. Yates, D.; Sieber, J.; Purkey, D.; Huber-Lee, A. WEAP21-A demand-, priority-, and preference-driven water planning model: Part 1: Model characteristics. Water Int. 2005, 30, 487-500. [CrossRef] 
36. Forni, L.; Escobar, M.; Cello, P.; Marizza, M.; Nadal, G.; Girardin, L.; Losano, F.; Bucciarelli, L.; Young, C.; Purkey, D. Navigating the Water-Energy Governance Landscape and Climate Change Adaptation Strategies in the Northern Patagonia Region of Argentina. Water 2018, 10, 794. [CrossRef]

37. Alamanos, A.; Latinopoulos, D.; Xenarios, S.; Tziatzios, G.; Mylopoulos, N.; Loukas, A. Combining hydro-economic and water quality modeling for optimal management of a degraded watershed. J. Hydroinform. 2019, 21, 1118-1129. [CrossRef]

38. Hadded, R.; Nouiri, I.; Alshihabi, O.; Maßmann, J.; Huber, M.; Laghouane, A.; Yahiaoui, H.; Tarhouni, J. A Decision Support System to Manage the Groundwater of the Zeuss Koutine Aquifer Using the WEAP-MODFLOW Framework. Water Resour. Manag. 2013, 27, 1981-2000. [CrossRef]

39. Lempert, R.J.; Groves, D.G.; Popper, S.W.; Bankes, S.C. A General, Analytic Method for Generating Robust Strategies and Narrative Scenarios. Manag. Sci. 2006, 52, 514-528. [CrossRef]

40. Simpson, M.; James, R.; Hall, J.W.; Borgomeo, E.; Ives, M.C.; Almeida, S.; Kingsborough, A.; Economou, T.; Stephenson, D.; Wagener, T. Decision Analysis for Management of Natural Hazards. Annu. Rev. Environ. Resour. 2016, 41, 489-516. [CrossRef]

41. Pahl-Wostl, C.; Sendzimir, J.; Jeffrey, P.; Aerts, J.; Berkamp, G.; Cross, K. Managing Change toward Adaptive Water Management through Social Learning. Ecol. Soc. 2007, 12. [CrossRef]

42. Vorosmarty, C.J.; Hoekstra, A.Y.; Bunn, S.E.; Conway, D.; Gupta, J. Fresh water goes global. Science 2015, 349, 478-479. [CrossRef]

43. Liu, Y.; Gupta, H.; Springer, E.; Wagener, T. Linking science with environmental decision making: Experiences from an integrated modeling approach to supporting sustainable water resources management. Environ. Model. Softw. 2008, 23, 846-858. [CrossRef]

44. Loucks, D.P.; Kindler, J.; Fedra, K. Interactive Water Resources Modeling and Model Use: An Overview. Water Resour. Res. 1985, 21, 95-102. [CrossRef]

45. Halbe, J.; Pahl-Wostl, C.; Lange, M.A.; Velonis, C. Governance of transitions towards sustainable development-The waterenergy-food nexus in Cyprus. Water Int. 2015, 40, 877-894. [CrossRef]

46. Halbe, J.; Adamowski, J.; Bennett, E.M.; Pahl-Wostl, C.; Farahbakhsh, K. Functional organization analysis for the design of sustainable engineering systems. Ecol. Eng. 2014, 73, 80-91. [CrossRef]

47. Purkey, D.R.; Escobar Arias, M.I.; Mehta, V.K.; Forni, L.; Depsky, N.J.; Yates, D.N.; Stevenson, W.N. A Philosophical Justification for a Novel Analysis-Supported, Stakeholder-Driven Participatory Process for Water Resources Planning and Decision Making. Water 2018, 10, 1009. [CrossRef]

48. Forni, L.G.; Galaitsi, S.E.; Mehta, V.K.; Escobar Arias, M.I.; Purkey, D.R.; Depsky, N.J.; Lima, N.A. Exploring scientific information for policy making under deep uncertainty. Environ. Model. Softw. 2016, 86, 232-247. [CrossRef]

49. MMAyA. Modelación Estratégica de la Cuenca del Río Rocha; Ministerio de Medio Ambiente y Agua con apoyo financiero de la CAF: La Paz, Bolivia, 2018.

50. Boucher, O.; Servonnat, J.; Albright, A.L.; Aumont, O.; Balkanski, Y.; Bastrikov, V.; Bekki, S.; Bonnet, R.; Bony, S.; Bopp, L.; et al. Presentation and Evaluation of the IPSL-CM6A-LR Climate Model. J. Adv. Model. Earth Syst. 2020, 12, e2019MS002010. [CrossRef]

51. Schwalm, C.R.; Glendon, S.; Duffy, P.B. RCP8.5 tracks cumulative $\mathrm{CO}_{2}$ emissions. Proc. Natl. Acad. Sci. USA 2020, 117, 19656-19657. [CrossRef]

52. Hoogendam, P. Hydrosocial territories in the context of diverse and changing ruralities: The case of Cochabamba's drinking water provision over time. Water Int. 2019, 44, 129-147. [CrossRef]

53. Marston, A. The scale of informality: Community-run water systems in peri-urban Cochabamba, Bolivia. Water Altern. 2014, 7, 72-88.

54. Bakker, K. The ambiguity of community: Debating alternatives to private-sector provision of urban water supply. Water Altern. 2008, 1, 236-252.

55. Assies, W. David versus Goliath in Cochabamba: Water rights, neoliberalism, and the revival of social protest in Bolivia. Lat. Am. Perspect. 2003, 30, 14-36. [CrossRef]

56. Rocha López, R.; Boelens, R.; Vos, J.; Rap, E. Hydrosocial territories in dispute: Flows of water and power in an interbasin transfer project in Bolivia. Water Altern. 2019, 12, 267-284.

57. Myrland, J. Two-Dimensional Hydraulic Modeling for Flood Assessment of the Rio Rocha, Cochabamba, Bolivia; Uppsala University: Uppsala, Sweden, 2014.

58. Jacobson, S.; Sekizovic, I. Physico-Chemical Evaluation of the Water Quality in Rocha River: A Qualitative and Comparative Analysis Including Aspects of Social and Environmental Factors. Master's Thesis, Lund University, Lund, Sweden, 2019.

59. Zabalaga, J.; Amy, G.; von Münch, E. Evaluation of agricultural reuse practices and relevant guidelines for the Alba Rancho WWTP (primary and secondary facultative ponds) in Cochabamba, Bolivia. Water Sci. Technol. 2007, 55, 469-475. [CrossRef] [PubMed]

60. Cossio, C.; Perez-Mercado, L.F.; Norrman, J.; Dalahmeh, S.; Vinnerås, B.; Mercado, A.; McConville, J. Impact of treatment plant management on human health and ecological risks from wastewater irrigation in developing countries-Case studies from Cochabamba, Bolivia. Int. J. Environ. Health Res. 2019, 1-19. [CrossRef] [PubMed]

61. Perez-Mercado, L.F.; Lalander, C.; Joel, A.; Ottoson, J.; Iriarte, M.; Oporto, C.; Vinnerås, B. Pathogens in crop production systems irrigated with low-quality water in Bolivia. J. Water Health 2018, 16, 980-990. [CrossRef] [PubMed]

62. Sharifi, M.A.; van den Toorn, W.; Rico, A.; Emmanuel, M. Application of GIS and multicriteria evaluation in locating sustainable boundary between the tunari National Park and Cochabamba City (Bolivia). J. Multi Criteria Decis. Anal. 2002, 11, 151-164. [CrossRef] 
63. Programa Manejo Integral de Cuencas El Manejo Integral de Cuencas en el Desarrollo Local, un Proceso de Construcción y Aprendizaje; Fundación AGRECOL Andes: Cochabamba, Bolivia, 2004.

64. Cossío, V.; Wilk, J. A paradigm confronting reality: The river basin approach and local water management spaces in the Pucara Basin, Bolivia. Water Altern. 2017, 10, 181-194.

65. Bustamante, R.; Vega, D. Normas Indígenas y Consuetudinarias Sobre la Gestión del Agua en Bolivia; Wageningen University: Wageningen, The Nederlands, 2006; ISBN 90-8585-056-8.

66. Hendriks, J. Legislacion de Aguas y Gestión de Sistemas Hídricos en Países de la Región Andina. In Derechos Colectivos y Políticas Hídricas en la Región Andina; Urteaga, P., Boelens, R., Eds.; IEP Instituto de Estudios Peruanos: Lima, Peru, 2006 ; pp. 47-111.

67. Ministerio del Agua. Plan Nacional de Cuencas PNC: Marco Conceptual y Estratégico; Ministerio del Agua y Viceministerio de Cuencas y Recursos Hídricos: La Paz, Bolivia, 2007; p. 40.

68. Saldías, C.; Boelens, R.; Wegerich, K.; Speelman, S. Losing the watershed focus: A look at complex community-managed irrigation systems in Bolivia. Water Int. 2012, 37, 744-759. [CrossRef]

69. Ministerio de Medio Ambiente y Agua. Marco Orientador para la Formulación de Planes Directores de Cuencas (PDC); Viceministerio de Recursos Hídricos y Riego: La Paz, Bolivia, 2014.

70. Ministerio de Medio Ambiente y Agua. Programa Plurianual de Gestión Integrada de Recursos Hídricos y Manejo Integral de Cuencas 2017-2020; Viceministerio de Recursos Hídricos y Riego: La Paz, Bolivia, 2017.

71. Servicio Departamental de Cuencas. Elaboración del diagnóstico de situación de la gestión, uso y manejo del agua de la cuenca del río Rocha; Servicio Departamental de Cuencas: Cochabamba, Bolivia, 2013.

72. Lempert, R.J.; Popper, S.W.; Bankes, S.C. Shaping the Next One Hundred Years: New Methods for Quantitative, Long-Term Policy Analysis; RAND: Santa Monica, CA, USA, 2003; ISBN 0-8330-3275-5.

73. Ministerio de Medio Ambiente y Agua. Balance Hídrico Superficial de Bolivia; Ministerio de Medio Ambiente y Agua: La Paz, Bolivia, 2018.

74. Lehner, B.; Verdin, K.; Jarvis, A. New Global Hydrography Derived From Spaceborne Elevation Data. Eos Trans. Am. Geophys. Union 2008, 89, 93-94. [CrossRef]

75. Programa de Desarrollo Agropecuario Sustentable. Inventario Nacional de Presas de Bolivia 2010; Programa de Desarrollo Agropecuario Sustentable: Cochabamba, Bolivia, 2010; ISBN 978-99954-774-3-1.

76. Ministerio de Medio Ambiente y Agua. Plan Maestro Metropolitano de Agua y Saneamiento de Cochabamba Bolivia; Ministerio de Medio Ambiente y Agua: Cochabamba, Bolivia, 2014.

77. Chapra, S.C. Surface Water Quality Modeling; McGraw-Hill: New York, NY, USA, 1997.

78. Allen, R.G.; Pereira, L.S.; Raes, D.; Smith, M. Crop evapotranspiration-Guidelines for computing crop water requirements-FAO Irrigation and drainage paper 56. FAO Rome 1998, 300, D05109.

79. Diseño Conceptual del Componente Riego del Proyecto Misicuni; Ministerio de Medio Ambiente y Agua; C3B Consultora Boliviana Beccar Bottega Ltda: Cochabamba, Bolivia, 2016.

80. Balance Hídrico de la Producción Agrícola en el Valle Central de Cochabamba; Programa de Enseñanza e Investigación en Riego Andino y de los Valles; Centro de Levantamientos Aeroespaciales y Aplicaciones de SIG para el Desarrollo Sostenible de los Recursos Naturales: Cochabamba, Bolivia, 1999.

81. Ministerio de Medio Ambiente y Agua. Inventario Nacional de Sistemas de Riego 2012; Viceministerio de Recursos Hídricos y Riego: La Paz, Bolivia, 2012.

82. Ministerio de Medio Ambiente y Agua. Guía Metodológica para la Elaboración de Balances Hídricos Superficiales; Viceministerio de Recursos Hídricos y Riego: La Paz, Bolivia, 2016.

83. Moriasi, D.; Gitau, M.; Pai, N.; Daggupati, P. Hydrologic and Water Quality Models: Performance Measures and Evaluation Criteria. Trans. ASABE 2015, 58, 1763-1785. [CrossRef]

84. Yates, D.; Gangopadhyay, S.; Rajagopalan, B.; Strzepek, K. A technique for generating regional climate scenarios using a nearest-neighbor algorithm. Water Resour. Res. 2003, 39, 1199. [CrossRef]

85. Decreto Departamental $N^{\circ}$ 4544; Gobierno Autónomo Departamental de Cochabamba: Cochabamba, Bolivia, 2020 ; p. 3.

86. Rocha López, R.; Hoogendam, P.; Vos, J.; Boelens, R. Transforming hydrosocial territories and changing languages of water rights legitimation: Irrigation development in Bolivia's Pucara watershed. Geoforum 2019, 102, 202-213. [CrossRef]

87. Lund, J.R.; Palmer, R.N. Water resource system modeling for conflict resolution. Water Resour. Update 1997, 3, 70-82.

88. Nandalal, K.D.W.; Simonovic, S.P. Resolving conflicts in water sharing: A systemic approach. Water Resour. Res. 2003, 39. [CrossRef]

89. Hoogendam, P.; Boelens, R. Dams and Damages. Conflicting Epistemological Frameworks and Interests Concerning “Compensation" for the Misicuni Project's Socio-Environmental Impacts in Cochabamba, Bolivia. Water 2019, 11, 408. [CrossRef] 